\title{
Belowground in situ redox dynamics and methanogenesis recovery in a degraded fen during dry-wet cycles and flooding
}

\author{
C. Estop-Aragonés ${ }^{1, *}$, K.-H. Knorr ${ }^{1}$, and C. Blodau ${ }^{1, *}$ \\ ${ }^{1}$ Limnological Research Station \& Department of Hydrology, University of Bayreuth, Universitätsstrasse 30, \\ 95447 Bayreuth, Germany \\ * present address: Hydrology Group, Institute of Landscape Ecology, FB 14 Geosciences, \\ University of Münster, Germany \\ Correspondence to: C. Blodau (christian.blodau@uni-muenster.de)
}

Received: 17 July 2012 - Published in Biogeosciences Discuss.: 29 August 2012

Revised: 11 December 2012 - Accepted: 21 December 2012 - Published: 24 January 2013

\begin{abstract}
Climate change induced drying and flooding may alter the redox conditions of organic matter decomposition in peat soils. The seasonal and intermittent changes in pore water solutes $\left(\mathrm{NO}_{3}^{-}, \mathrm{Fe}^{2+}, \mathrm{SO}_{4}^{2-}, \mathrm{H}_{2} \mathrm{~S}\right.$, acetate) and dissolved soil gases $\left(\mathrm{CO}_{2}, \mathrm{O}_{2}, \mathrm{CH}_{4}, \mathrm{H}_{2}\right)$ under natural water table fluctuations were compared to the response under a reinforced drying and flooding in fen peats. Oxygen penetration during dryings led to $\mathrm{CO}_{2}$ and $\mathrm{CH}_{4}$ degassing and to a regeneration of dissolved electron acceptors $\left(\mathrm{NO}_{3}^{-}, \mathrm{Fe}^{3+}\right.$ and $\left.\mathrm{SO}_{4}^{2-}\right)$. Drying intensity controlled the extent of the electron acceptor regeneration. Iron was rapidly reduced and sulfate pools $\sim 1$ $\mathrm{mM}$ depleted upon rewetting and $\mathrm{CH}_{4}$ did not substantially accumulate until sulfate levels declined to $\sim 100 \mu \mathrm{mol} \mathrm{L}^{-1}$. The post-rewetting recovery of soil methane concentrations to levels $\sim 80 \mu \mathrm{mol} \mathrm{L}^{-1}$ needed $40-50$ days after natural drought. This recovery was prolonged after experimentally reinforced drought. A greater regeneration of electron acceptors during drying was not related to prolonged methanogenesis suppression after rewetting. Peat compaction, solid phase content of reactive iron and total reduced inorganic sulfur and organic matter content controlled oxygen penetration, the regeneration of electron acceptors and the recovery of $\mathrm{CH}_{4}$ production, respectively. Methane production was maintained despite moderate water table decline of $20 \mathrm{~cm}$ in denser peats. Flooding led to accumulation of acetate and $\mathrm{H}_{2}$, promoted $\mathrm{CH}_{4}$ production and strengthened the co-occurrence of iron and sulfate reduction and methanogenesis. Mass balances during drying and flooding indicated that an important fraction of the electron flow must have been used for the generation and consumption of electron accep-
\end{abstract}

tors in the solid phase or other mechanisms. In contrast to flooding, dry-wet cycles negatively affect methane production on a seasonal scale, but this impact might strongly depend on drying intensity and on the peat matrix, of which structure and physical properties influence moisture content.

\section{Introduction}

Peatlands store up to 550 Gigatons of carbon (C), which represents twice the $\mathrm{C}$ storage of the global forest biomass (Parish et al., 2008), in about $3 \%$ of the world's land area. The main factors supporting peat accumulation are water saturation and anoxia that almost extends to the peat surface. The anoxia prevailing under water-logged conditions favours slow organic matter $(\mathrm{OM})$ decomposition and peat accumulation, whereas aerobic conditions usually associated with water unsaturated peat favour faster respiration and, thus, prevent peat accumulation. Climate models predict an increased frequency and intensity of heat waves and intense precipitation events, which favour the occurrence of droughts and floods (Meehl et al., 2007). Such predictions raise concern regarding the rates and form of released $\mathrm{C}$ from peatlands in response to these hydrological changes. The effects of temporary change in water table (WT) have been commonly evaluated by monitoring the exchange of $\mathrm{CO}_{2}$ and $\mathrm{CH}_{4}$. High WT commonly led to greater $\mathrm{CH}_{4}$ emissions, whereas WT decline was usually followed by an increase of $\mathrm{CO}_{2}$ emissions and a decrease of $\mathrm{CH}_{4}$ emissions (Aurela et al., 2007; Elberling et al., 2011; Hogg et al., 1992; Silvola et al., 1996). 
The release of $\mathrm{CO}_{2}$ and $\mathrm{CH}_{4}$ to the atmosphere results from the production, consumption and transport of these gases in peat at rates that vary with soil moisture levels, depth and vegetation community. Peat quality, oxygen content, nutrient content and temperature were identified as important controls on OM decomposition (Hogg et al., 1992; Minkkinen et al., 2007; Yavitt et al., 1997). Anaerobic decomposition of $\mathrm{OM}$ is mediated by syntrophic cooperation of microbes. Initially, OM is degraded by exoenzymatic action through depolymerisation and hydrolytic reactions. Fermentation processes subsequently generate $\mathrm{CO}_{2}$, low-molecular weight carbon monomers, $\mathrm{H}_{2}$, formate and acetate. These electron donors serve as substrates for additional $\mathrm{CO}_{2}$ production coupled to the reduction of electron acceptors and for hydrogenotrophic or acetotrophic $\mathrm{CH}_{4}$ production (Appelo and Postma, 2005; Hamberger et al., 2008). The energy yield of terminal electron accepting processes (TEAPs) for the oxidation of a given substrate follows the sequence aerobic $>$ anaerobic respiration: $\mathrm{Mn}$ reduction $>\mathrm{NO}_{3}^{-}$reduction $>\mathrm{Fe}$ (III) reduction $(\mathrm{FeR})>$ Sulfate reduction $(\mathrm{SR})>$ Methanogenesis (Hoehler et al., 1998). The range of substrate concentrations, and particularly of dissolved hydrogen, is indicative of the predominant redox process in anaerobic subsurface environments and, for a given TEAP, there is a threshold concentration below which hydrogen cannot be metabolised (Cordruwisch et al., 1988; Hoehler et al., 1998).

During drying, temporal shifts in TEAPs were related to WT decline due to the oxygen input in peat which inhibited methanogenesis and led to a regeneration of electron acceptors (Knorr and Blodau, 2009; Knorr et al., 2009; Shannon and White, 1996). A delay of methane production and emission to recover pre-drought values is commonly observed upon rewetting (Kettunen et al., 1999) and is usually explained by the availability of alternative electron acceptors after drying (Freeman et al., 1994). To assess the impact of drying on methane production, an important greenhouse gas, it is, thus, also important to evaluate the post drought effects on methanogenesis and the role of potential methanogenesis suppression by alternative electron acceptors. The effects that alternative electron acceptors have on the suppression of $\mathrm{CH}_{4}$ have widely been investigated under controlled conditions (Achtnich et al., 1995; Dowrick et al., 2006; Ratering and Conrad, 1998), but results for in situ conditions are scarce and little information exists about the effects of variable drying intensity on postdrought methanogenesis. Pore water chemistry in peat is temporally and spatially variable in response to precipitation events (Mitchell and Branfireun, 2005 ) and the redox zonation in peat soils undergoing drywet cycles and flooding has not been investigated in detail. We are also lacking information about the pore water chemistry of the unsaturated zone. Chemical data was mostly collected from water saturated peat in field studies (Shannon and White, 1996) and the few reports showing TEAPs in the unsaturated zone were carried out with peat mesocosms (Deppe et al., 2010; Knorr et al., 2009) and did not evaluate TEAPs under flooded conditions. Additionally, in situ mass balances establishing the redox electron flow during OM decomposition are lacking to explain the sources of electron acceptors associated to $\mathrm{CO}_{2}$ production.

To address these knowledge gaps, pore water and soil gas chemistry in peat soils were analysed over time in a degraded fen under natural conditions and compared to dryingrewetting and flooding manipulations during two seasons. We expected drying to favour oxygen intrusion, deplete the stored dissolved inorganic carbon (DIC) and methane due to degassing, and renew electron acceptors in peat. After rewetting we expected instead a build-up of DIC, depletion of oxygen and electron acceptors, and a prolonged delay in the recovery of $\mathrm{CH}_{4}$ production. Interested in quantifying and relating these dynamics to the drying intensity, we hypothesised more severe drought to cause a greater regeneration of electron acceptors, i.e., sulfate and ferric iron, that would lead to a longer suppression of methanogenesis upon rewetting. To test our expectations we (1) quantified the regeneration of electron acceptors during drying and related it to drying intensity, (2) evaluated the potential suppression of methanogenesis by alternative electron acceptors after rewetting and (3) related the post-drought delay of methanogenesis to the preceding drying intensity. Additionally, the impact of prolonged water saturated conditions, i.e., flooding, on $\mathrm{CH}_{4}$ production was evaluated and quantified. Peat physical and physicochemical properties influencing redox sequences were also identified. We estimated $\mathrm{CO}_{2}$ and $\mathrm{CH}_{4}$ production, $\mathrm{O}_{2}$ consumption, turnover rates of dissolved electron acceptors and evaluated the electron flow balance related to $\mathrm{O}_{2}$ consumption during drying and to $\mathrm{CO}_{2}$ production during flooding.

\section{Material and methods}

\subsection{Site description and experimental design}

The Schlöppnerbrunnen site is a small $(<1$ ha) soligenous and moderately sloped fen within a Picea abies forest located in the Fichtelgebirge region, north-east of Bavaria, at $\sim 750 \mathrm{~m}$ above sea level. The region has undergone peat extraction until $\sim 1950$ (Firbas and v. Rochow, 1956) and relicts of historic drainage ditches are still present. Peat is well decomposed (H7-H9, von Post scale), has a high and variable mineral content with depth and forms a $50-70 \mathrm{~cm}$ thick deposit with a clay horizon underneath. Mean annual temperature is $\sim 5^{\circ} \mathrm{C}$ and precipitation in the catchment ranges between 900 and $1160 \mathrm{~mm} \mathrm{yr}^{-1}$.

The site is displayed in Fig. 1. Water table was manipulated in three plots (D1, D2 and D3; D plots) relative to controls (C1, C2 and C3; C plots). D plots were drained and rewetted in 2008 and flooded in 2009. Drainage manipulation lasted from day of year (DOY) 165 until DOY 218 


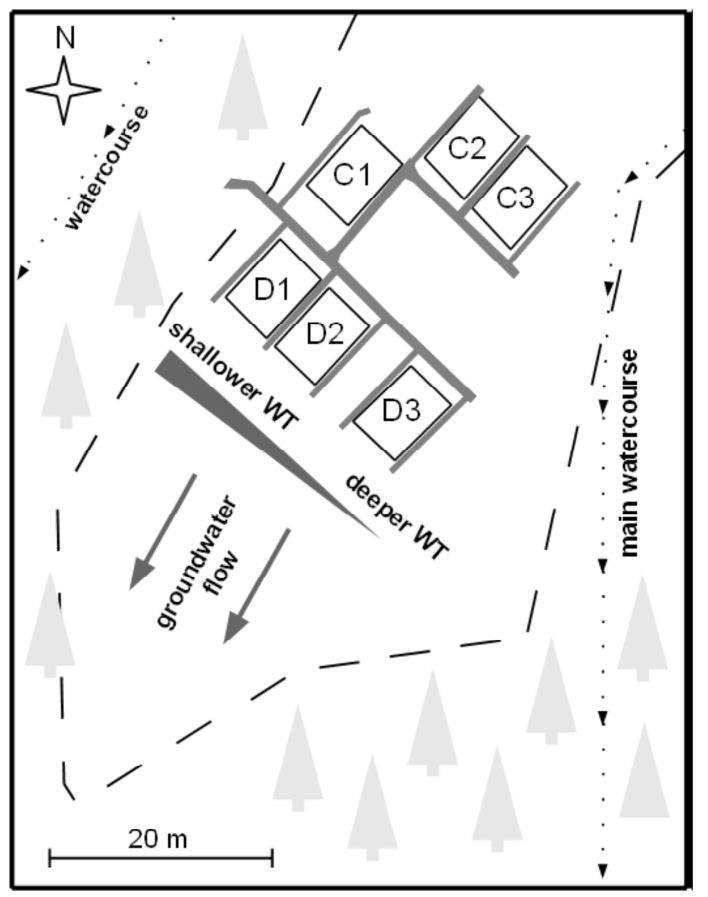

Fig. 1. Sketch of the fen site. Six experimental plots, each $7 \times 5 \mathrm{~m}$, were designed and accessed using wooden platforms. Water table was manipulated (drying/rewetting in 2008 and flooding in 2009) in plots D1, D2 and D3. No manipulation took place in plots C1, $\mathrm{C} 2$ and $\mathrm{C} 3$. Water from the main watercourse was used to irrigate $\mathrm{D}$ plots during the flooding. Note that D plots had deeper mean WT compared to $\mathrm{C}$ plots in addition to the lateral water table (WT) gradient. Peat properties also differed among plots (refer to Table 1; Estop-Aragonés et al., 2012). Copyright 2012 American Geophysical Union. Reproduced by permission of American Geophysical Union.

(13 June to 5 August) by installing a roof and pumping water from ditches filled with gravel and topsoil. The roof excluded $\sim 140 \mathrm{~mm}$ of precipitation in D plots. Rewetting took place by sprinkling an irrigate similar to rain water (Knorr et al., 2009) providing $103 \mathrm{~mm}$ for $\sim 8 \mathrm{~h}$. The roof was then removed and WT allowed fluctuating in D plots until the flooding. In 2009, water from a stream was channelled and discharged using perforated PVC-pipes to flood D plots from DOY 135 to DOY 303 (15 May to 30 October). Each plot $\left(\sim 35 \mathrm{~m}^{2}\right)$ received a minimum average of $70 \mathrm{~m}^{3} \mathrm{~d}^{-1}$ discharged water $\left(\mathrm{pH} 4.6\right.$, in $\mathrm{mg} \mathrm{L}^{-1}, \mathrm{DO} \sim 6$, nitrate $\sim 3.75$, sulfate $\sim 14$, DOC $\sim 15$, DON $\sim 0.4$ ) during the flooding, which mostly ran off by overland flow and implied an input of electron acceptors in peat. The flooding was useful to observe in situ processes in peat soils under continued anaerobic conditions, but it must be noted that such a prolonged event is unlikely to occur in this particular site under natural conditions considering the slight site slope $\left(5^{\circ}\right)$ and the large quantities of water discharged.
Previous studies on these plots (Estop-Aragonés et al., 2012; Knorr et al., 2009) identified a lateral gradient of WT (Fig. 1), and of peat properties (Table 1). This gradient influenced the response of soil gas and pore water chemistry to WT changes. $\mathrm{C}$ plots had higher mean water table than D plots, and northwestern plots higher than southeastern ones. Bulk density decreased with OM content $(p<0.005)$. Peat in C2, C3 and D3 had the highest bulk density (Table 1). The total reduced inorganic sulfur (TRIS) content positively correlated with OM content $(p<0.005)$, had a variable depth distribution, was lowest in $\mathrm{C} 2, \mathrm{C} 3$ and $\mathrm{D} 3$, and ranked D2 $>$ D1 $>$ D3 within D plots and $\mathrm{C} 1>\mathrm{C} 2>\mathrm{C} 3$ within $\mathrm{C}$ plots (Table 1). Solid phase reactive ferric iron content $(1 \mathrm{~N} \mathrm{HCl}$ extractable) was highest in the upper $5 \mathrm{~cm}$ of peat, decreased with depth by a factor 2 to 8 , and was lower in C2, C3 and D3 compared to the other plots (Table 1). Respiratory and methanogenic activity in this fen concentrated in the top soil (Estop-Aragonés and Blodau, 2012; Reiche et al., 2010). Vegetation is dominated by vascular plants. In its northwestern part, vegetation comprises mainly Carex rostrata and patches of Sphagnum fallax, and Nardus stricta, Agrostis sp., Molinia caerulea and Eriophorum vaginatum dominate towards the southeast. Samplers and sensors were installed in the narrow hollows covered by decaying litter from vascular plants. The mean pore water $\mathrm{pH}$ was 4.8 .

\subsection{Installations, soil gas and pore water sampling, analysis and quantification}

Piezometers with calibrated pressure transducers recorded the WT hourly, which refers to the distance between the position of the groundwater table and the peat surface. In each plot gas samplers (silicone tubes allowing diffusive equilibration) and water samplers (MacroRhizon ${ }^{\circledR}$, UMS GmbH) were horizontally inserted at depths of $2.5,5,7.5,10,12.5$, $15,17.5,20,25$ and $30 \mathrm{~cm}$ in the peat profile and connected to the surface by polyurethane tubes connected to stopcocks. Peat temperature and moisture sensors were installed at depths of $5,10,15$ and $20 \mathrm{~cm}$, or at 5 and $15 \mathrm{~cm}$ depending on the plot. Further information on use and calibration of sensors was already presented (Estop-Aragonés et al., 2012).

Gas and pore water was sampled usually weekly (2008) and biweekly (2009) using $10 \mathrm{~mL}$ plastic syringes (Carl Roth $\mathrm{GmbH})$. Gas samples $(\sim 7 \mathrm{~mL})$ were transferred within $2 \mathrm{~h}$ after collection into $\mathrm{RAM}^{\mathrm{TM}}$ vials with screw caps PTFE/Butyl Liner $9 \mathrm{~mm}$ (Alltech). Concentrations of $\mathrm{O}_{2}$, $\mathrm{CO}_{2}$ and $\mathrm{CH}_{4}$ were measured by gas chromatography and thermal conductivity $\left(\mathrm{O}_{2}, \mathrm{CO}_{2}\right)$ or flame ionisation $\left(\mathrm{CH}_{4}\right)$ detection (Agilent GC 6890, Carboxen column), and quantified with certified gas standards $\left(\mathrm{CO}_{2}, \mathrm{CH}_{4}\right)$ and dilutions from synthetic air $\left(\mathrm{O}_{2}\right)$. In 2009, hydrogen concentrations were investigated; $2 \mathrm{~mL}$ of the soil gas sample were transferred immediately after collection in $\mathrm{N}_{2}$-flushed vials, analysed the day after on a Trace Analyser (AMETEK ta3000), 
Table 1. Bulk density (BD), organic matter (OM), solid phase contents of total reduced inorganic sulfur (TRIS) and reactive ferric iron Fe(III) among the investigated plots. All values are means (and SD) from $30 \mathrm{~cm}$ peat profiles (Estop-Aragonés et al., 2012; Knorr et al., 2009). Note the comparatively high BD, low OM and low TRIS and Fe(III) in D3, C2 and C3. The TRIS and Fe(III) content were not monitored during the periods evaluated in this study and are only shown in this table (and figures) to emphasise the differences among plots.

\begin{tabular}{rrrrr}
\hline Plot & $\mathrm{BD}^{\mathrm{a}}\left(\mathrm{g} \mathrm{cm}^{-3}\right)$ & $\mathrm{OM} \mathrm{content}^{\mathrm{a}}(\% \mathrm{wt})$ & $\mathrm{TRIS}^{\mathrm{b}}\left(\mu \mathrm{mol} \mathrm{g} \mathrm{dw}^{-1}\right)$ & $\mathrm{Fe}(\mathrm{III})^{\mathrm{c}}\left(\mu \mathrm{mol} \mathrm{g} \mathrm{dw}{ }^{-1}\right)$ \\
\hline D1 & $0.13(0.09)$ & $79.5(4.3)$ & $14.8(6.8)$ & $211.1(316.0)$ \\
$\mathrm{D} 2$ & $0.08(0.02)$ & $82.3(5.2)$ & $17.4(6.6)$ & $217.7(307.2)$ \\
D3 & $0.17(0.07)$ & $78.0(5.8)$ & $6.9(2.5)$ & $116.1(119.9)$ \\
C1 & $0.08(0.04)$ & $82.7(4.1)$ & $18.3(8.7)$ & $227.3(258.8)$ \\
C2 & $0.15(0.05)$ & $71.8(8.1)$ & $7.0(1.9)$ & $101.9(100.1)$ \\
C3 & $0.20(0.05)$ & $58.7(13.0)$ & $7.5(1.9)$ & $88.3(46.6)$ \\
\hline
\end{tabular}

a Averaged from measurements determined at $5 \mathrm{~cm}$ intervals.

b Averaged from 0-5, 5-10, 10-20 and 20-30 cm measurements; sum of acid volatile sulfur ( 2 to $7 \%$ ) and chromium reducible sulfur (93 to $98 \%$ ).

c Averaged from $0-5,5-10,10-20$ and 20-30 cm measurements; acid extraction (1 N HCl). The content was disproportionally highest in the $0-5 \mathrm{~cm}$ interval.

and quantified with dilutions from a certified standard. We report dissolved concentrations (DO, DIC, $\mathrm{CH}_{4}$ and $\mathrm{H}_{2}$ ) of the measured gases calculated based on Henry's constant corrected for temperature (Sander, 1999). Concentrations of DIC were calculated using the carbonic acid equilibrium constant and measured $\mathrm{pH}$ values.

Pore water samples $(\sim 10 \mathrm{~mL})$ were prepared on site by transfer of aliquots of $2 \mathrm{~mL}$ in cuvettes containing $50 \mu \mathrm{L} \mathrm{HCl}$ for iron or $750 \mu \mathrm{L}$ zinc acetate solution for sulfide. Dissolved $\mathrm{Fe}^{2+}$ was measured photometrically $(512 \mathrm{~nm})$ using the phenantroline method (Tamura et al., 1974) and ascorbic acid was added to calculate total dissolved iron and, by difference, dissolved ferric iron. Sulfides were measured photometrically using the methylene-blue method at $665 \mathrm{~nm}$ (Hofmann and Hamm, 1967). Sulfate, nitrate and acetate concentrations were determined using ion chromatography with chemical suppression and conductivity detector (Anion Dual 3 column, Metrohm $\mathrm{GmbH}$ ). A glass electrode (Mettler Toledo) was used to measure $\mathrm{pH}$ on site. The speciation of sulfides into bisulfide ion ( $\mathrm{HS}^{-}$) was considered using $\mathrm{pH}$ (Stumm and Morgan, 1996).

\subsection{Calculation of net turnover rates and electron flow balance}

A mass balance approach and Fick's first law were used to calculate net turnover rates of species based on the change of concentrations over time:

$R_{N}=\frac{\Delta S_{A}}{\Delta t}+\left[D_{A} \frac{\Delta C_{A}, \text { upper }}{\Delta x}\right]_{\text {upper }} z^{-1}-\left[D_{A} \frac{\Delta C_{A}, \text { lower }}{\Delta x}\right]_{\text {lower }} z^{-1},(1)$

where $R_{N}\left[\mathrm{NL}^{-3} \mathrm{~T}^{-1}\right]$ is the turnover rate of a species $A$, $\Delta S_{A} / \Delta t\left[\mathrm{NL}^{-3} \mathrm{~T}^{-1}\right]$ the change of storage over time between consecutive measurements in a layer with thickness $z$ [L]. The expressions in parentheses represent the diffusive flux at the upper and lower boundary of a layer where $D_{A}$ is the diffusion coefficient in peat $\left[\mathrm{L}^{2} \mathrm{~T}^{-1}\right]$ and $\Delta C_{A} / \Delta x$ is the concentration gradient at the upper or lower end of the segment $\left[\mathrm{NL}^{-4}\right]$. The calculation of $D_{A}$ for each species was corrected for temperature and calculated as $D_{A}=D_{O} \cdot \xi$ where $D_{O}$ is the diffusion coefficient in water or in air and $\xi$ is the tortuosity factor. Under saturated conditions for solutes and gases, $\xi=\varphi^{2}$ (Lerman, 1988) where $\varphi$ is total porosity. Under unsaturated conditions, we corrected $\varphi$ for solutes based on the air filled porosity (AFP) to account for only the water filled peat volume, and for gases we used a conservative approach for undisturbed soils where $\xi=0.66 \cdot$ AFP $\cdot\left(\text { AFP } \cdot \varphi^{-1}\right)^{3}$ (Moldrup et al., 1997). The prediction of the diffusivity $\left(D_{A}\right)$ of gases in the unsaturated zone is very uncertain during WT fluctuations (Elberling et al., 2011; Koehler et al., 2010), and rates also vary strongly depending on the chosen model to describe $D_{A}$ (Pingintha et al., 2010). It must also be noted that this approach (Eq. 1) assumes that there is no advective transport of species (lateral flow of water) and restricts the mass balance to vertical diffusive transport.

All estimated rates were integrated for the $30 \mathrm{~cm}$ peat layer. Rates were time-averaged over a given period considering the elapsed time between sampling. Periods representative for different WT conditions were chosen. Time-averaged rates refer, thus, to values over a given period, whereas peak rates refer to a temporary maximum. Pools of a given compound formed or consumed during a given period were calculated to perform electron flow balances. Electron flow balances during flooding were calculated assuming $\mathrm{CO}_{2}$ production based on $\mathrm{C}$ species with an oxidation state of 0 (Deppe et al., 2010), and assuming constant and permanent electron acceptor concentrations of the irrigate in the surface as reported above. Nitrate was reduced to $\mathrm{N}_{2}\left(5 / 4 \mathrm{~mol} \mathrm{CO}_{2}\right.$ per mol nitrate), $\mathrm{Fe}(\mathrm{III})$ reduced to $\mathrm{Fe}^{2+}\left(1 / 4 \mathrm{~mol} \mathrm{CO}_{2}\right.$ per mol iron) and sulfate reduced to $\mathrm{H}_{2} \mathrm{~S}\left(2 \mathrm{~mol} \mathrm{CO}_{2}\right.$ per mol sulfate). We assumed $1 \mathrm{~mol}$ of $\mathrm{CO}_{2}$ was produced per each mol of $\mathrm{CH}_{4}$, and $1 \mathrm{~mol} \mathrm{CO}_{2}$ was produced per each mol of acetate, maximum $\mathrm{CO}_{2}$ yield of common fermentation processes (Conrad, 1999). An electron flow balance was 
completed during drying to estimate the fraction of $\mathrm{O}_{2}$ consumed by reoxidation of dissolved electron acceptors and by $\mathrm{CO}_{2}$ production, i.e., 4 moles electron equivalents were transferred per mole $\mathrm{O}_{2}$ consumed.

\section{Results}

\subsection{Environmental and water table conditions}

Air temperature averaged $6.9^{\circ} \mathrm{C}(2008)$ and $6.6^{\circ} \mathrm{C}(2009)$ and ranged from $-16.4^{\circ} \mathrm{C}$ to $28.4^{\circ} \mathrm{C}$. Peat temperature showed day-night cycles of decreasing amplitude with depth and ranged between $0.2{ }^{\circ} \mathrm{C}$ and $16.8^{\circ} \mathrm{C}$ in $\mathrm{C}$ plots at $5 \mathrm{~cm}$ depth. In $\mathrm{D}$ plots, at $5 \mathrm{~cm}$ depth, drying lead to $\sim 1{ }^{\circ} \mathrm{C}$ higher maximum temperatures, whereas flooding kept peat $\sim 1.5^{\circ} \mathrm{C}$ cooler than in $\mathrm{C}$ plots (Fig. S1). Water table fluctuated over time and all WT rises were linked to precipitation events under natural conditions on control plots. Seasonal drying occurred in early summer in 2008 and WT declined to $-50 /-70 \mathrm{~cm}$ for $\sim 35 \mathrm{~d}$, and in late summer in 2009 to $-25 /-45 \mathrm{~cm}$ for $\sim 60 \mathrm{~d}$. The WT manipulation in D plots reinforced the drying in 2008 and WT declined to $-70 /-80 \mathrm{~cm}$ for $\sim 65 \mathrm{~d}$ (Fig. S1). The drying intensity, thus, ranked "Reinforced drying 2008" (D plots) > "Seasonal drying 2008" (C plots) > "Seasonal drying 2009" (C plots). Air filled porosity reflected WT fluctuations and the rank of drying intensity, and the response of AFP to WT change was influenced by peat compaction (Fig. S2, Table 1).

\subsection{Oxygen, DIC and methane}

Concentrations of dissolved gases responded to WT changes, as expected. Oxygen and DIC dynamics are shown in Figs. 2 and 3, respectively. These figures are reprints of a previous manuscript and will not be described here in detail. Oxygen dynamics were controlled by the position and the change in WT, and strongly controlled the dynamics of other gases and solutes. Seasonal drying in $\mathrm{C}$ plots led to oxygen penetration with concentrations near saturation levels $\left(>300 \mu \mathrm{mol} \mathrm{L}^{-1}\right)$, and oxygen intrusion was deeper in 2008 than in 2009. The reinforced drying in 2008 in D plots extended by about 30 days the seasonal aeration observed under natural conditions. Upon rewetting, oxygen penetration became immediately shallower, indicating reduced diffusive transport rates compared to dry conditions. During flooding, anoxic conditions were maintained throughout 2009 in D plots (Fig. 2). The anaerobic conditions during post-rewetting and the delayed oxygen intrusion during seasonal drying 2009 observed in $\mathrm{C} 2$ and $\mathrm{C} 3$ indicate that bulk density also controlled oxygen penetration, which is in agreement with the smaller change in AFP upon WT fluctuations in those plots (Fig. S2). DIC concentrations responded inversely to oxygen dynamics. The DIC pool declined during seasonal drying (C plots), and the prolonged drying (D plots) led to lower concentrations by the end of the event due to enhanced degassing.

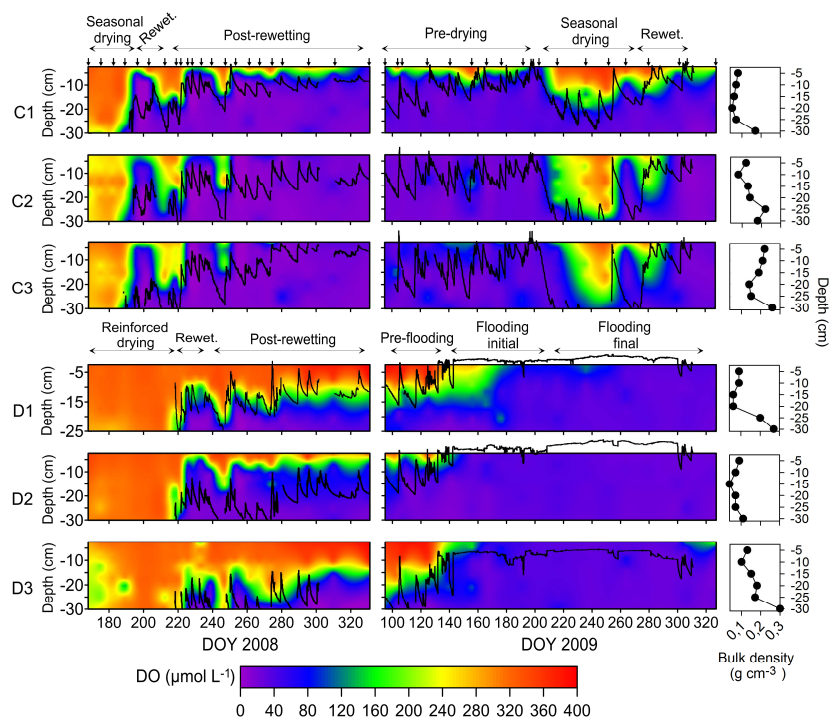

Fig. 2. Dissolved oxygen (DO) concentrations in fen peat profiles during changes in water table (solid black line, not shown below 30 or $25 \mathrm{~cm}$ depth). Sampling frequency is indicated on top with arrows. Different hydrological periods and the depth distribution of bulk density are also shown (Estop-Aragonés et al., 2012). Copyright 2012 American Geophysical Union. Modified by permission of American Geophysical Union.

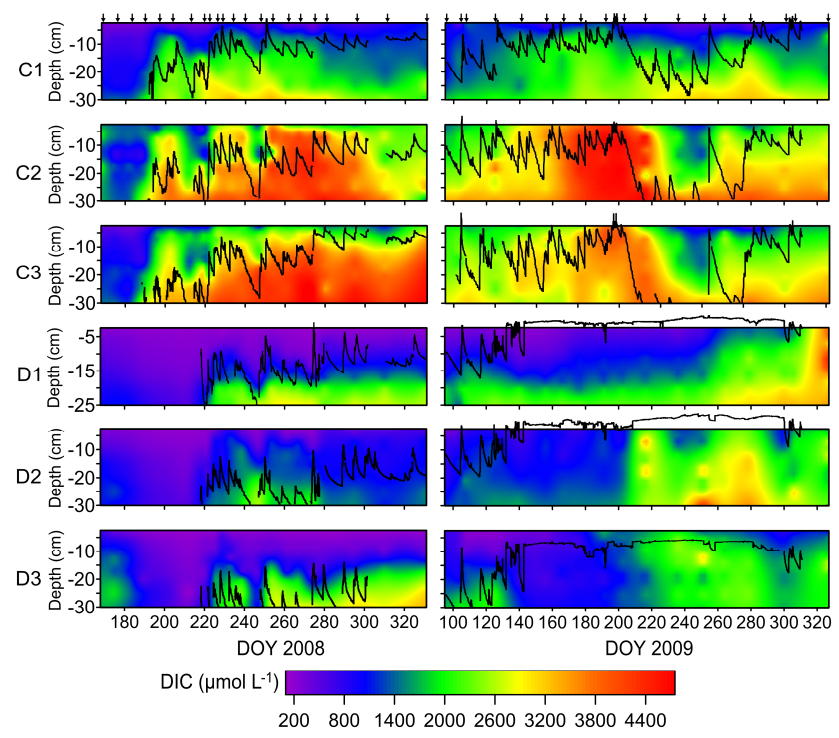

Fig. 3. Dissolved inorganic carbon (DIC) concentrations. Refer to caption in Fig. 2 (Estop-Aragonés et al., 2012). Copyright 2012 American Geophysical Union. Reproduced by permission of American Geophysical Union.

Upon rewetting, DIC rapidly accumulated in water saturated peat depths to levels $>2 \mathrm{mmol} \mathrm{L}^{-1}$ indicating increased DIC storage capacity. During flooding, the highest DIC concentrations in D plots were observed reaching $>3 \mathrm{mmol} \mathrm{L}^{-1}$ (Fig. 3). 


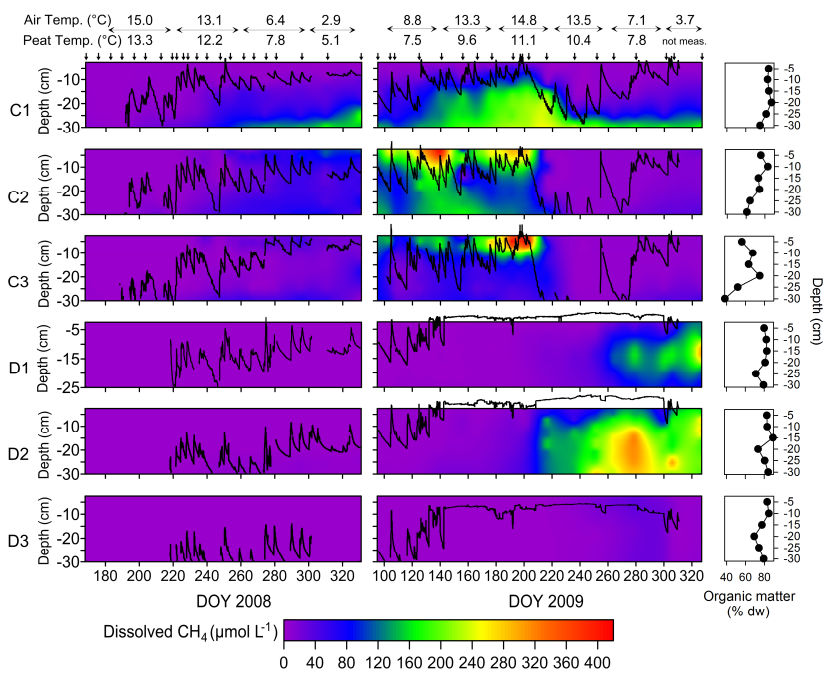

Fig. 4. Dissolved methane concentrations. Refer to caption in Fig. 2. Air and peat $(5 \mathrm{~cm}$ depth) temperature values are means of hourly measurements over periods of 40 days. The depth distribution of organic matter content in \% dry weight is also shown.

Methane was depleted during the drying of the peat. In 2008 , methane was initially not detected in C or D plots because the WT was already at $-40 \mathrm{~cm}$ at the beginning of measurements but the missing response of concentrations to WT decline was recorded during seasonal drying in 2009 (C plots). Accumulation of $\mathrm{CH}_{4}$ in peat after drying varied with treatment and season. Upon rewetting, concentrations reached $\sim 80 \mu \mathrm{mol} \mathrm{CH}_{4} \mathrm{~L}^{-1}$ at some depths $40-50$ days after seasonal drying 2008 (C plots), whereas after the reinforced drying 2008 (D plots), null or negligible accumulation, to a maximum of $10 \mu \mathrm{mol} \mathrm{CH} \mathrm{CH}^{-1}$ in D2, occurred for the rest of 2008 and beginning of 2009 (Fig. 4). Comparing both seasonal dryings (C plots), the deeper WT in 2008 led to methane depletion at all depths, whereas in 2009 intermittent recovery of WT during drying maintained higher background levels in deeper layers before rewetting started (see $\mathrm{C} 1$ in Fig. 4). The WT fluctuations during the post-rewetting phase were also shallower in 2009 and occurred under colder conditions compared to 2008 (C plots in Fig. 4, Fig. S1). During flooding, the highest methane concentrations in D plots were observed with a variable response ranking D2 $>$ D1 $>$ D3, which coincided with the rank for DIC concentrations and the inverse rank for oxygen penetration previous to the flooding.

Methane accumulated above $10 \mathrm{~cm}$ depths whenever $\mathrm{O}_{2}$ was absent indicating fast production in the upper unsaturated peat (see C plots, Figs. 2 and 4). Due to a greater moisture retention in compacted peat, methane concentrations $>100 \mu \mathrm{mol} \mathrm{L}^{-1}$ were maintained in the unsaturated zone despite WT decline to $-20 \mathrm{~cm}$. Methane concentrations strongly decreased with little change in air filled porosity, but the gas was still detected at transient air filled porosities up to

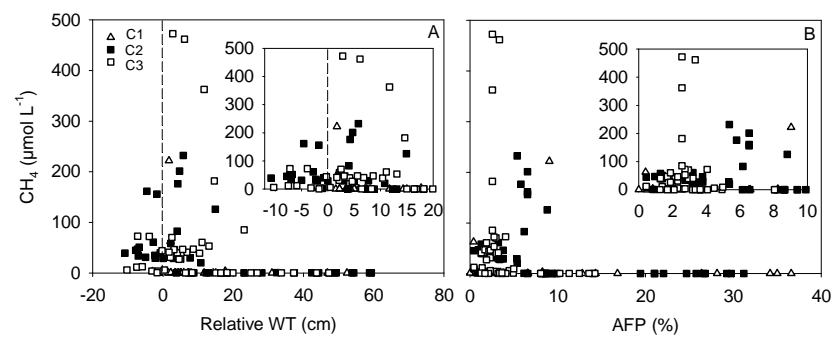

Fig. 5. Relations between dissolved methane with (A) relative water table and (B) air filled porosity (AFP) in C plots. The relative WT expresses the distance between the water table and the depth at which the sample was obtained; negative values indicated watersaturated peat and positive values refer to water-unsaturated conditions. Note the different distribution in relation to differences in peat compaction (refer to Table 1)

around $6 \%$ in peats with bulk density $>0.12 \mathrm{~g} \mathrm{~cm}^{-3}$ in the upper layer (Fig. 5, note in Fig. 4 C2, C3 DOY $\sim 140$ and $\sim 200$ in 2009).

\subsection{Nitrate, dissolved $\mathrm{Fe}^{2+}$ and sulfate}

The response of solutes to WT changes followed the expected dynamics. Nitrate concentrations randomly increased to levels between 20 and $150 \mu \mathrm{mol} \mathrm{L}^{-1}$ at some depths during drying and immediately decreased after rewetting (not shown). Levels of dissolved $\mathrm{Fe}^{2+}$ rapidly decreased during drying in unsaturated peat. Upon rewetting, $\mathrm{Fe}^{2+}$ immediately accumulated for 20-30 days, decreased afterwards (D1, D2, D3, C1), or kept increasing slowly over time (C2, C3) (Fig. 6). This short-lived $\mathrm{Fe}^{2+}$ accumulation was stronger in 2008 than in 2009 for a given C plot suggesting that rewetting after a more severe dryness led to greater $\mathrm{Fe}^{2+}$ release. In agreement with the depth distribution of solid phase ferric iron content (Fig. 6, Table 1), dissolved $\mathrm{Fe}^{2+}$ accumulated in the upper peat layer when $\mathrm{O}_{2}$ was absent. This became much more prominent during flooding when $\mathrm{Fe}^{2+}$ levels were 13.6 (D2), 6.7 (D1) and 5 (D3) times higher than maximum levels under non-flooded conditions in each respective plot.

Sulfate concentrations increased during drying and peaked before the last sampling of the drying phase. Sulfate release was influenced by the drying intensity, total reduced inorganic sulfur (TRIS) content and peat compaction. Averaged concentrations at the last sampling of each drying were $479 \pm 308,279 \pm 153$ and $170 \pm 31 \mu \mathrm{mol} \mathrm{SO}_{4}^{2-} \mathrm{L}^{-1}$ for the reinforced drying 2008, seasonal drying 2008 and the less severe seasonal drying 2009, respectively (Fig. 7). For a given drying, the sulfate release ranked $\mathrm{D} 2>\mathrm{D} 1>\mathrm{D} 3$ (2008) within D plots, and C1 $>\mathrm{C} 2>\mathrm{C} 3$ within $\mathrm{C}$ plots in both years despite the different seasonal drought intensity in 2008 and 2009. These sequences reflect TRIS content (Table 1, Fig. 7). Sulfate release depended on oxygen penetration and its onset was, thus, retarded in more compacted peat; seasonal drying in 2009 occurred simultaneously in all 


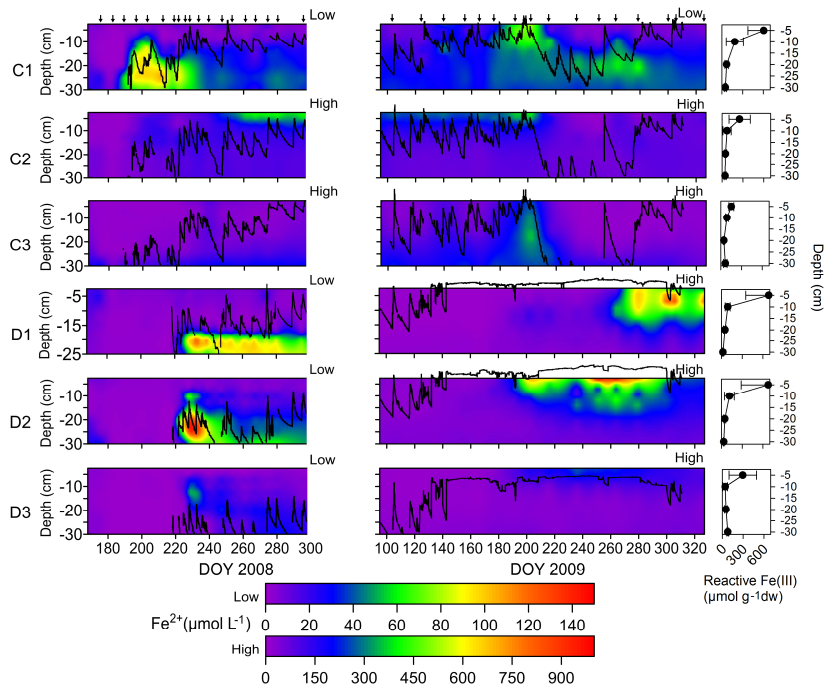

Fig. 6. Dissolved ferrous $\left(\mathrm{Fe}^{2+}\right)$ concentrations. Refer to caption in Fig. 2. Note the different scales. During flooding up to $2 \mathrm{mmol} \mathrm{L}^{-1}$ were detected in D2 (not shown for clarity). The depth distribution of reactive ferric iron content in the solid phase is shown to emphasise the differences among plots, but it was not measured in this study (Table 1).

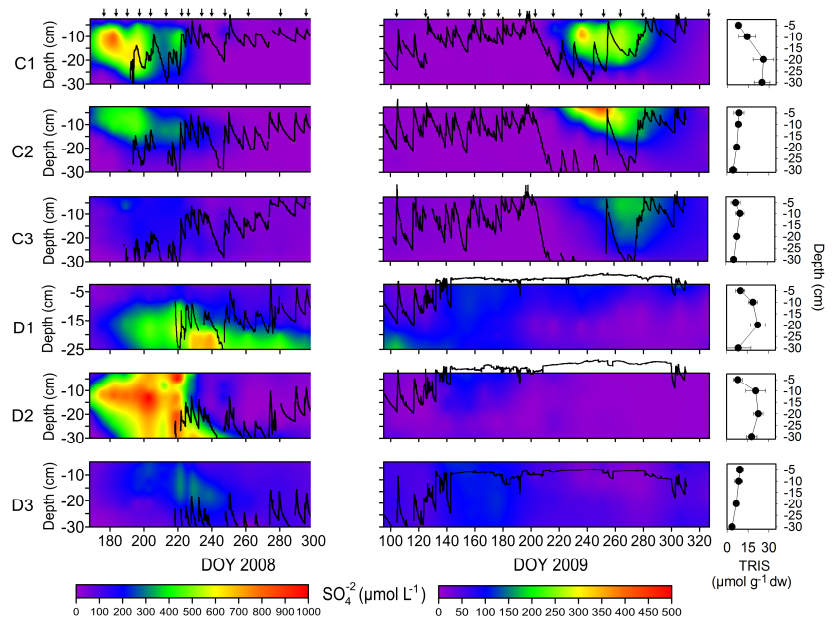

Fig. 7. Sulfate $\left(\mathrm{SO}_{4}^{2-}\right)$ concentrations. Refer to caption in Fig. 2. The depth distribution of TRIS content in the solid phase is shown to emphasise the differences among plots, but it was not measured in this study (Table 1).

C plots, but the increase of sulfate concentrations occurred later in $\mathrm{C} 2$ and especially in $\mathrm{C} 3$ due to the retarded oxygen intrusion in those denser peats (Figs. 2 and 7).

Upon rewetting, the sulfate pool formed during drying was consumed within variable time periods (Fig. 7). The inverse sulfate and methane dynamics indicate that SR strongly dampened methanogenesis (Figs. 4 and 7). Stronger methane accumulation occurred when sulfate levels dropped to $\sim 100 \mu \mathrm{mol} \mathrm{L}^{-1}$ or below. Just after rewetting, methane re-

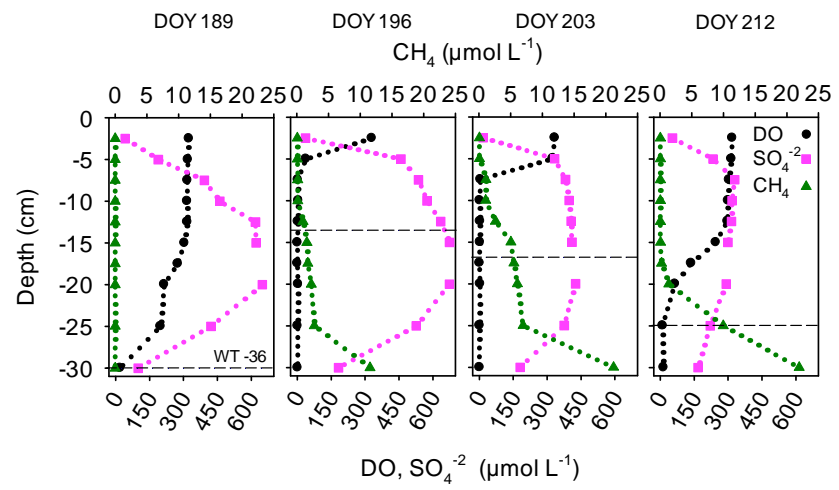

Fig. 8. Illustration of the "recovery" of dissolved methane concentrations after the seasonal drying 2008 in the $\mathrm{C} 1$ plot. The last measurement during drying was on day of year (DOY) 189 and the first upon rewetting was on DOY 196. During that transition ("dry to wet") sulfate levels increased, but also did methane concentrations. Methane continued accumulating whereas sulfate levels started decreasing (DOY 203) and this pattern was reversed when WT declined allowing oxygen penetration (DOY 212). The dashed line indicates the water table position.

lease was slowest, but not absolutely inhibited. Small quantities of methane accumulated within the first sampling interval of 7 days in the deepest layers while sulfate concentrations were about $500 \mu \mathrm{mol} \mathrm{L}^{-1}$, indicating a co-occurrence of both processes (Fig. 8). This was observed in C plots, but not in D plots after the reinforced drying. Regarding the effects of dryness intensity in 2008, about 60 days after rewetting sulfate concentration was on average only $20 \pm 17 \mu \mathrm{mol} \mathrm{L}^{-1}$ in C plots (DOY 261), but $119 \pm 110 \mu \mathrm{mol} \mathrm{L}^{-1}$ in D plots (DOY 280). This would indicate an effect of drying intensity. However, there were also differences in oxygen penetration between treatments; peat layers 5 to $10 \mathrm{~cm}$ deep were consistently more aerated after rewetting in D plots compared to C plots (Fig. 2). This aeration must have contributed to the prolonged $\mathrm{CH}_{4}$ accumulation delay by about a year observed in D plots after drying. For this reason it is difficult to assign the delay in $\mathrm{CH}_{4}$ production recovery to the impact of the reinforced drying in comparison to $\mathrm{C}$ plots and to quantify it. Some insight may be gained from comparing the D2 to the $\mathrm{C} 1$ plot, where post-rewetting peat aeration was similar, but the delay in $\mathrm{CH}_{4}$ production differed, suggesting that the larger drying intensity on D1 influenced the prolonged delay.

Interestingly, a greater sulfate pool generated during a given drying did not entail a longer delay in $\mathrm{CH}_{4}$ accumulation after rewetting; instead the delay became even shorter. As mentioned, the sulfate pool formed during drying ranked $\mathrm{C} 1>\mathrm{C} 2>\mathrm{C} 3$ within $\mathrm{C}$ plots and $\mathrm{D} 2>\mathrm{D} 1>\mathrm{D} 3$ within D plots. However, upon rewetting, fastest sulfate depletion and strongest and sooner $\mathrm{CH}_{4}$ accumulation occurred in $\mathrm{C} 1$ and D2 although they generated a greater sulfate pool during drying. Noteworthy, these plots (C1 and D2) had the lowest $\mathrm{BD}$, the highest $\mathrm{OM}$ content and also the highest TRIS 
and ferric iron content (Table 1). The faster sulfate consumption and $\mathrm{CH}_{4}$ accumulation in $\mathrm{D} 2$ might result from the shallower oxygen penetration compared to other D plots. However, among $\mathrm{C}$ plots, the fast sulfate depletion occurred in the most aerated $\mathrm{C} 1$ plot, which stresses the role of OM content and quality for $\mathrm{CH}_{4}$ production recovery after drying. This data, thus, indicate that greater sulfate regeneration during drying does not necessarily imply a longer delay in $\mathrm{CH}_{4}$ production recovery after rewetting since this relation is greatly influenced by TRIS and OM content in peat (Fig. S4).

During flooding, the irrigate provided an input of sulfate and nitrate that also delayed methane production. Prior to flooding (DOY 104-125 in 2009) sulfate levels were between 10 and $100 \mu \mathrm{mol} \mathrm{L}^{-1}$ and nitrate levels up to $14 \mu \mathrm{mol} \mathrm{L}^{-1}$ depending on depth. Once flooded (DOY 140), concentrations increased to a homogeneous value of $\sim 100 \mu \mathrm{mol} \mathrm{SO}_{4}^{2-} \mathrm{L}^{-1}$ (Fig. 7) and $\sim 40 \mu \mathrm{molNO}_{3}^{-} \mathrm{L}^{-1}$. Despite this continuous electron acceptor input from the surface, methanogenesis proceeded. The spatiotemporal pattern of sulfate consumption broadly matched that of $\mathrm{CH}_{4}$ accumulation (Figs. 4 and 7). The highest concentrations of sulfides were observed during flooding (Table 2) and ranked D2 $>$ D1 $>$ D3 in agreement with the ranking observed also for $\mathrm{CH}_{4}$, DIC, $\mathrm{Fe}^{2+}$, acetate and $\mathrm{H}_{2}$.

\subsection{Acetate and dissolved hydrogen}

Acetate was not detected during non-flooded conditions in $\mathrm{C}$ plots except for few random samples at levels not higher than $18 \mu \mathrm{mol} \mathrm{L}^{-1}$ and a sporadic peak of $147 \mu \mathrm{mol} \mathrm{L}^{-1}$ in C2 at $2.5 \mathrm{~cm}$ depth coinciding with high $\mathrm{CH}_{4}$ concentrations (not shown). Similarly, dissolved $\mathrm{H}_{2}$, which was only measured in 2009, was mostly below $0.5 \mathrm{nmol} \mathrm{L}^{-1}$ in C plots. This is except for a few measurements in the upper $5 \mathrm{~cm}$ reaching $1 \mathrm{nmol} \mathrm{H}_{2} \mathrm{~L}^{-1}$ and a peak of $3 \mathrm{nmol} \mathrm{H}_{2} \mathrm{~L}^{-1}$ in $\mathrm{C} 3$ at high $\mathrm{CH}_{4}$ levels. In contrast, during flooding of D plots, acetate and hydrogen levels became consistently higher with some variation and temporal pattern (Fig. 9). Acetate and hydrogen levels were highest in D2 reaching $760 \mu$ mol acetate $\mathrm{L}^{-1}$ and $28 \mathrm{nmol} \mathrm{H}_{2} \mathrm{~L}^{-1}$ at depths above $5 \mathrm{~cm}$, intermediate in D1 reaching $120 \mu \mathrm{mol}$ acetate $\mathrm{L}^{-1}$ and $22 \mathrm{nmol} \mathrm{H}_{2} \mathrm{~L}^{-1}$ at 10-20 cm depth, and lowest or not detectable in D3 reaching only $100 \mu \mathrm{mol}$ acetate $\mathrm{L}^{-1}$ in the upper $5 \mathrm{~cm}$. Acetate and hydrogen concentrations remained high until DOY 279 and substantially decreased thereafter (DOY 306) (Fig. 9). This trend matched with the seasonal temperature decrease occurring during that period, when mean daily temperature could decline from 14 to below $0{ }^{\circ} \mathrm{C}$ for air and from 9 to $4{ }^{\circ} \mathrm{C}$ for peat $(5 \mathrm{~cm}$ depth). A similar decrease of concentrations accompanying this temperature decline was also observed for $\mathrm{CH}_{4}$, DIC, $\mathrm{Fe}^{2+}$ and dissolved sulfides.

The abundance of $\mathrm{H}_{2}$ and acetate during flooding apparently favoured a co-occurrence of FeR, SR and methanogenesis. Regarding the vertical distribution of redox processes, SR occurred at deeper layers initially and extended upwards

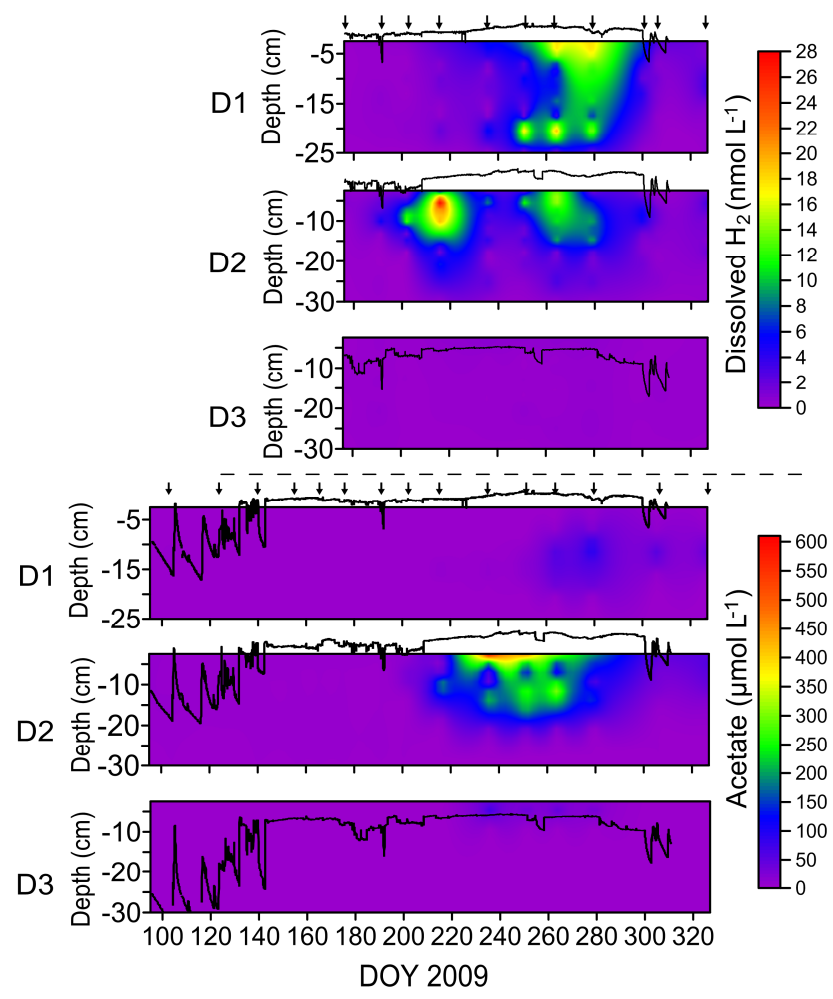

Fig. 9. Dissolved hydrogen and acetate concentrations during flooding (D plots). No or weak and sporadic accumulation occurred in C plots (see text)

with time reaching intermediate layers in D1 and upper layers in D2. FeR mainly dominated in the uppermost layer, and $\mathrm{CH}_{4}$ accumulated with time down from intermediate layers. Despite this broad redox zonation with each process prevailing in a given zone, concentrations of $\mathrm{Fe}^{2+}$, sulfides and $\mathrm{CH}_{4}$ increased over several consecutive sampling intervals at a given depth indicating a spatial co-occurrence of these processes at our scale of observation. The variable pattern of $\mathrm{H}_{2}$ concentrations broadly mirrored these dynamics, and the redox processes co-occurrence was more apparent with increasing $\mathrm{H}_{2}$ levels, when $>2 \mathrm{nmol} \mathrm{L}^{-1}$ (Fig. S3).

\subsection{Dissolved electron acceptors turnover rates}

Peaks of FeR during rewetting events reached $3.08 \mathrm{mmol} \mathrm{Fe}^{2+} \mathrm{m}^{-2} \mathrm{~d}^{-1}$ although the highest estimate occurred during flooding and reached $4.68 \mathrm{mmol} \mathrm{Fe}^{2+} \mathrm{m}^{-2} \mathrm{~d}^{-1}$. Sulfate generation during drying peaked $9.88 \mathrm{mmol} \mathrm{SO}_{4}^{2-} \mathrm{m}^{-2} \mathrm{~d}^{-1}$ and upon rewetting, SR peaked $20.5 \mathrm{mmol} \mathrm{SO}_{4}^{2-} \mathrm{m}^{-2} \mathrm{~d}^{-1}$.

Time-averaged rates for the turnover of nitrate, iron and sulfate over periods with different WT conditions are shown in Fig. 10. Drying generated electron acceptors at time-averaged rates ranging from 0.01 to $1.04 \mathrm{mmol} \mathrm{NO}_{3}^{-} \mathrm{m}^{-2} \mathrm{~d}^{-1}$, from 
Table 2. Concentrations of sulfides $\left(\mu \mathrm{mol} \mathrm{L}{ }^{-1}\right)$ in control $(C)$ and manipulated (D) plots illustrating the effects of flooding. Values show mean with one standard deviation (SD) and maximum concentrations. No or lower values were observed during drying.

\begin{tabular}{llrrrrrr}
\hline & & D1 & D2 & D3 & C1 & C2 & C3 \\
\hline \multirow{2}{*}{ Rewetted conditions } & Mean (SD) & $0.1(0.6)$ & $1.5(3.4)$ & $<0.1(0.1)$ & $2.9(4.5)$ & $0.2(0.5)$ & $<0.1(<0.1)$ \\
& Max & 7.3 & 18.2 & 0.5 & 26.2 & 3.2 & 0.6 \\
\hline \multirow{2}{*}{ Flooding } & Mean (SD) & $3.3(5.4)$ & $12.4(8.6)$ & $0.9(2.4)$ & - & - & - \\
& Max & 26.0 & 41.2 & 15.6 & - & - & - \\
\hline
\end{tabular}

0.94 to $3.72 \mathrm{mmol} \mathrm{m}^{-2} \mathrm{SO}_{4}^{2-} \mathrm{d}^{-1}$ and from 0.09 to $1.30 \mathrm{mmol} \mathrm{Fe}(\mathrm{III}) \mathrm{m}^{-2} \mathrm{~d}^{-1}$ and from 1.09 to $3.75 \mathrm{mmol} \mathrm{Fe}(\mathrm{III}) \mathrm{m}^{-2} \mathrm{~d}^{-1}$ assuming $\mathrm{SO}_{4}^{2-}$ generated from $\mathrm{FeS}$ oxidation. During rewetting, lasting for about 20 days, electron acceptors were consumed at 0.04 to $0.64 \mathrm{mmol} \mathrm{NO}_{3}^{-} \mathrm{m}^{-2} \mathrm{~d}^{-1}, 0.25$ to $9.77 \mathrm{mmol} \mathrm{SO}_{4}^{2-} \mathrm{m}^{-2} \mathrm{~d}^{-1}$ and 0.12 to $1.13 \mathrm{mmol} \mathrm{Fe}(\mathrm{III}) \mathrm{m}^{-2} \mathrm{~d}^{-1}$. The pool of $\mathrm{SO}_{4}^{2-}$ reduced during rewetting was not balanced by concentrations of dissolved sulfides (refer to Table 2). Based on the measured $\mathrm{SO}_{4}^{2-}$ consumed, the sulfide formed was quantified (stoichiometry $1: 1$ ). Based on $\mathrm{Fe}^{2+}$ levels the precipitation of $\mathrm{FeS}_{2}$ (pyrite, $K_{\mathrm{sp}}=10^{-16.4}$ ) was possible upon rewetting but the solution was not supersaturated regarding $\mathrm{FeS}\left(K_{\mathrm{sp}}=10^{-4.2}\right)$ and $\mathrm{FeCO}_{3}\left(K_{\mathrm{sp}}=10^{-10.4}\right)$. This sink for sulfides and $\mathrm{Fe}^{2+}$ was apparent in $\mathrm{C} 1$ and $\mathrm{D} 2$ plots in rewetting of 2008; the pool of $\mathrm{Fe}^{2+}$ accumulated upon rewetting rapidly disappeared from solution matching the strong decrease of sulfate concentrations (Figs. 6 and 7) and the posterior accumulation of dissolved sulfides (not shown). Assuming that all $\mathrm{SO}_{4}^{2-}$ was consumed, i.e., sulfide formed and precipitated, iron reduction rates would increase up to a factor of 19 with values ranging from 0.13 to $10.27 \mathrm{mmol} \mathrm{Fe}$ (III) $\mathrm{m}^{-2} \mathrm{~d}^{-1}$. These values were included in Fig. 10. No effects on rates due to the reinforced drying occurred except for $\mathrm{D} 2$, where a higher $\mathrm{SO}_{4}^{2-}$ reduction rate occurred upon rewetting compared to control conditions. During flooding, rates decreased and consumption of electron acceptors ranged from 0.08 to $0.1 \mathrm{mmol} \mathrm{NO}_{3}^{-} \mathrm{m}^{-2} \mathrm{~d}^{-1}$, reduction from 0.13 to $0.24 \mathrm{mmol} \mathrm{SO}_{4}^{2-} \mathrm{m}^{-2} \mathrm{~d}^{-1}$ and from 0.31 to $0.71 \mathrm{mmol} \mathrm{Fe}$ (III) $\mathrm{m}^{-2} \mathrm{~d}^{-1}$.

\subsection{Oxygen, DIC and methane turnover rates}

Our estimates of time-averaged $\mathrm{O}_{2}$ gas consumption during drying periods ranged from 17.8 to $367.2 \mathrm{mmol} \mathrm{O}_{2} \mathrm{~m}^{-2} \mathrm{~d}^{-1}$, and dissolved $\mathrm{O}_{2}$ consumption decreased during the flooding phase (from DOY 140 to 327) at rates ranging from 0.24 to $0.43 \mathrm{mmol} \mathrm{O}_{2} \mathrm{~m}^{-2} \mathrm{~d}^{-1}$. Time-averaged rates of gaseous $\mathrm{CO}_{2}$ production during drying ranged between 5.2 and $146.1 \mathrm{mmol} \mathrm{CO}_{2} \mathrm{~m}^{-2} \mathrm{~d}^{-1}$, whereas DIC production during flooding ranged from 3.9 to $5.2 \mathrm{mmol}$ DIC m $\mathrm{m}^{-2} \mathrm{~d}^{-1}$. During flooding, DIC temporally peaked at $32.4 \mathrm{mmol} \mathrm{DIC} \mathrm{m}^{-2} \mathrm{~d}^{-1}$. Time-averaged rates of dissolved
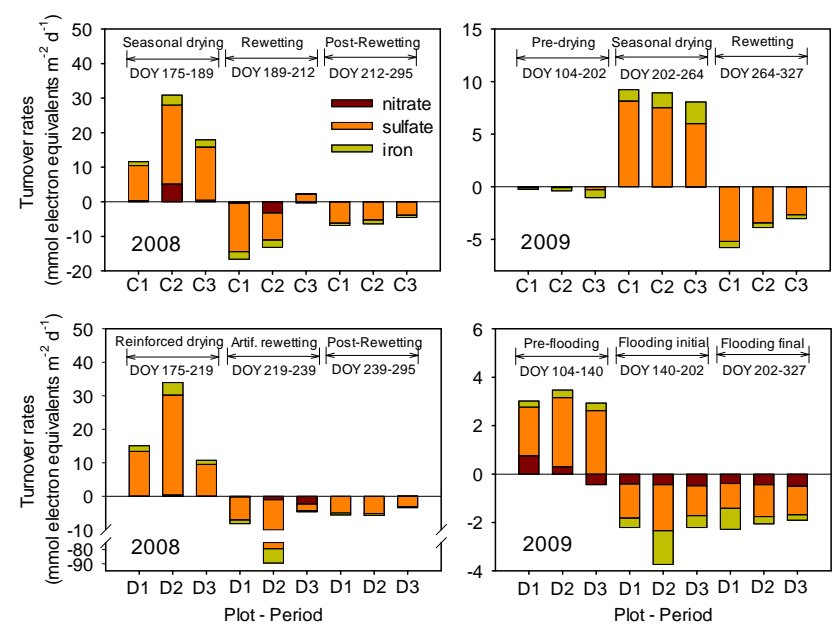

Fig. 10. Time-averaged net turnover rates of electron acceptors integrated for $30 \mathrm{~cm}$ profiles expressed in electron equivalents based on the dissolved concentrations measured (solutes) during different periods in all plots. Positive values refer to production (oxidation) and negative values to consumption (reduction).

methane production for the flooding phase ranged from 0.03 to $0.43 \mathrm{mmol} \mathrm{CH}_{4} \mathrm{~m}^{-2} \mathrm{~d}^{-1}$, whereas the estimate for the same time period in $\mathrm{C}$ plots shows a $\mathrm{CH}_{4}$ consumption (-0.01 to $-0.24 \mathrm{mmol} \mathrm{CH}_{4} \mathrm{~m}^{-2} \mathrm{~d}^{-1}$ ), which illustrates the importance of fluctuating WT and seasonal drying (C plots) against flooded conditions (D plots) for $\mathrm{CH}_{4}$ production. Nevertheless, gas $\mathrm{CH}_{4}$ production occasionally peaked to $40 \mathrm{mmol} \mathrm{CH}_{4} \mathrm{~m}^{-2} \mathrm{~d}^{-1}$ in control plots (C2 DOY 1402009 in Fig. 2, refer also to Fig. 5), whereas dissolved methane production during flooding peaked only at $1.83 \mathrm{mmol} \mathrm{CH}_{4} \mathrm{~m}^{-2} \mathrm{~d}^{-1}$.

\subsection{Electron flow balance}

Consumption of $\mathrm{O}_{2}$ was quantified against $\mathrm{CO}_{2}$ production and regeneration of dissolved electron acceptors to evaluate these sinks for $\mathrm{O}_{2}$ during drying in 2008 (Fig. 11a). The regeneration of the dissolved pool of electron acceptors (shown in Fig. 10) accounted only between 2 and $25 \%$ and $\mathrm{CO}_{2}$ production between 29 and $40 \%$ of the estimated $\mathrm{O}_{2}$ consumption. Based on these estimations, additional sinks not accounted for in our analysis consumed 

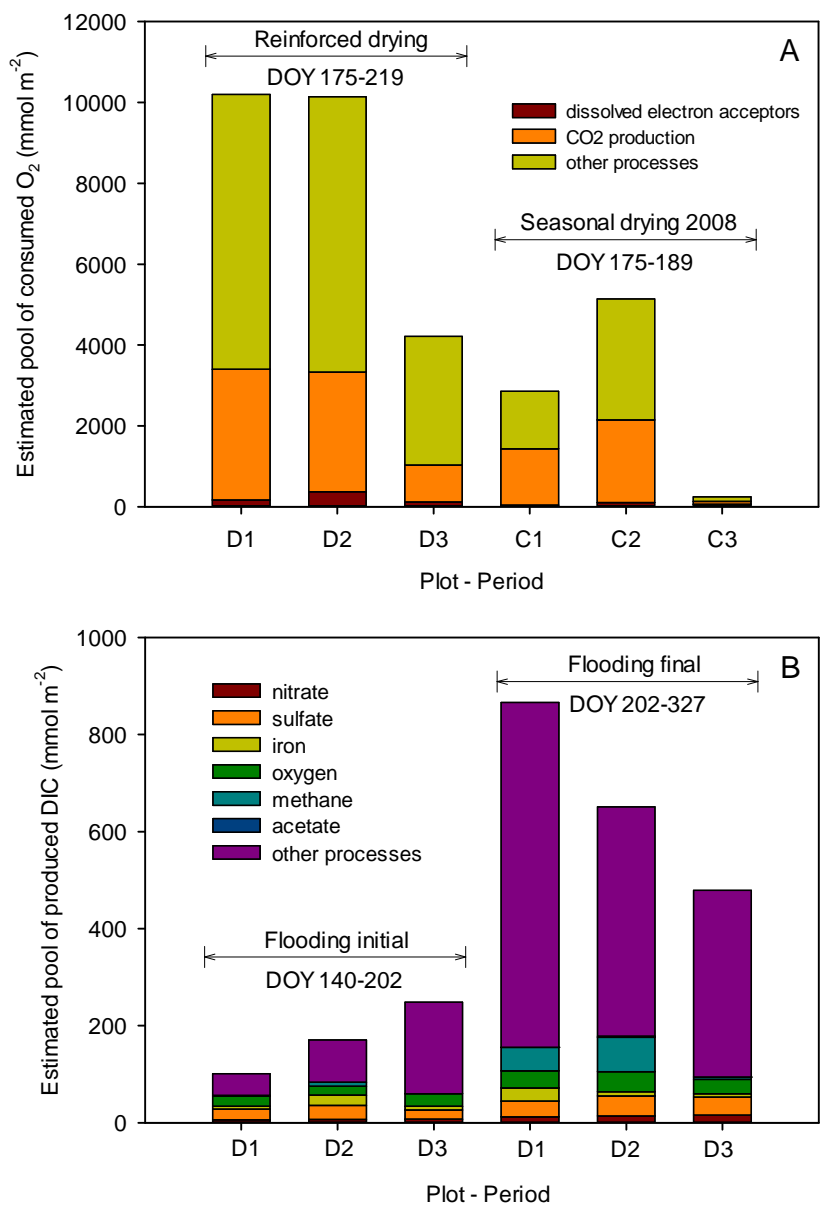

Fig. 11. (A) Cumulative pool of $\mathrm{O}_{2}$ consumed during seasonal and reinforced drying in 2008. Oxygen consumption explained all $\mathrm{CO}_{2}$ production in the gas phase and all the renewed electron acceptors (shown in Fig. 10) during drying. (B) Cumulative pool of DIC produced over time during flooding and fractions explained by dissolved electron acceptors, methanogenesis and acetate production. Other processes like the regeneration and consumption of electron acceptors in the solid phase likely constituted an important fraction of the unexplained $\mathrm{O}_{2}$ consumption during drying and of $\mathrm{CO}_{2}$ production during flooding, respectively (see text).

$\mathrm{O}_{2}$ during drying at time-averaged rates ranging between 32 and 850 mmol electron equivalents $\mathrm{m}^{-2} \mathrm{~d}^{-1}$, representing between 46 and $75 \%$ of the estimated $\mathrm{O}_{2}$ consumption (Fig. 11a). It must be noted that the low end of this range stems from plot $\mathrm{C} 3$, and certainly is an outlier when compared with measured $\mathrm{CO}_{2}$ fluxes (J. Muhr, personal communication, 2011). Such results reflect the poor description of diffusive transport and $D_{A}$ in that compacted and likely tortuous peat matrix (Fig. 11a).

During flooding, the consumption of dissolved electron acceptors and the production of methane and acetate were not balanced by the DIC produced (Fig. 11b). The proportion of DIC explained by these processes decreased as time after flooding passed, and declined from $24-55 \%$ dur- ing the initial (DOY 140-202) to 18-27\% during the final period (DOY 202-327). Consumption of dissolved electron acceptors initially accounted for $22-51 \%$ of the electron flow and decreased to $10-18 \%$ during the final period, whereas the fraction of methanogenesis increased from $0-5 \%$ to $1-11 \%$ with time (Fig. 11b). Acetate production was negligible in the balance $(<1 \%)$. Additional processes not accounted for in our analysis produced $\mathrm{CO}_{2}$ at timeaveraged rates (entire flooding period) ranging between 12 and $16 \mathrm{mmol}$ electron equivalents $\mathrm{m}^{-2} \mathrm{~d}^{-1}$.

\section{Discussion}

The results confirmed that changes in soil moisture levels strongly influence redox processes through the impact on diffusivity, which strongly controls gas transport rates in peat. Dry-wet cycles and flooding led to a contrasting response regarding terminal metabolism during OM decomposition by altering the balance between respiration and fermentation. Based on the observations in this minerotrophic site, we analyse the dynamics of redox processes in the three phases drying, rewetting and post-rewetting and compare these with the effects during flooding.

\subsection{Electron acceptor release during drying}

Electron acceptor regeneration was related to the WT decline and duration of drought. The WT decline had a stronger influence than duration for sulfate regeneration, given the sitespecific depth distribution of TRIS and organic sulfur content. This seems reasonable because of the deeper oxygen intrusion, the greater change in soil moisture and the greater surface area by reduced water film thickness with a deeper WT decline (Figs. S2 and 2). Maximum sulfate release also occurred before the end of drying indicating the fast regeneration of electron acceptors. Chemical oxidation of reduced iron is also a fast process at $\mathrm{pH}$ value of 4 to 5 (Ahmad and Nye, 1990), a range observed before drying (not shown). According to the kinetics of these processes, short, frequent and moderate drying events are important for the regeneration of electron acceptors and, thus, a suppression of methanogenesis. In addition to drought intensity, the solid phase content (TRIS and Fe(III)) and peat compaction (Table 1) influenced the extent and rate of the electron acceptor renewal. For a given drought, namely the seasonal drying 2008, a TRIS content of about $6.3 \mathrm{~mol} \mathrm{~m}^{-2}$ (upper $30 \mathrm{~cm}$ peat) led to mean $\mathrm{SO}_{4}^{2-}$ levels $\left(388 \mu \mathrm{mol} \mathrm{L}^{-1}\right)$ about $60 \%$ higher than in peats with a TRIS content of $\sim 3.7 \mathrm{~mol} \mathrm{~m}^{-2}$. Peats with a mean bulk density of $0.20 \mathrm{~g} \mathrm{~cm}^{-3}$ retarded electron acceptor regeneration by up to two weeks compared to less compacted peat of $0.08 \mathrm{~g} \mathrm{~cm}^{-3}$ (refer to seasonal drying 2009, Figs. 2 and 7). This delay correlated with slow oxygen intrusion into dense peats. We, thus, conclude that drought intensity, the TRIS and solid phase iron content and peat compaction, which was 
controlled by the ash content, determined the extent of the electron acceptor regeneration during drying (Fig. S4).

Oxygen consumption was not balanced by production of $\mathrm{CO}_{2}$ and release of dissolved electron acceptors during dry periods (Fig. 11a). A possible sink for $\mathrm{O}_{2}$ was the oxidation of $\mathrm{FeS}_{2}$ because only $0.8 \%$ to $39 \%$ of the $\mathrm{FeS}_{2}$ pool would have been oxidised. On the other hand, we did not find the large quantities of sulfate, at 30 times the level of measured concentrations that should have been released by this process. Similarly, if oxygen was consumed during ferrous iron oxidation and formed ferrihydrite, concentrations of dissolved $\mathrm{Fe}^{2+}$ should have increased upon rewetting up to tens of $\mathrm{mmol} \mathrm{L}^{-1}$. Instead we only detected the element on a micromolar level. In a previous report using mesocosms $60 \mathrm{~cm}$ deep, drought of 50 days duration and a WT decline to $-55 \mathrm{~cm}$ led to a total release of up to $157 \mathrm{mmol}$ electron acceptor equivalents $\mathrm{m}^{-2} \mathrm{~d}^{-1}$ in these peats. A major fraction of up to $\sim 90 \%$ of this release stemmed from the solid phase rather than the dissolved pool (Knorr and Blodau, 2009). Of the total renewed pool $>70 \%$ was consumed with time after rewetting in that experiment (Knorr and Blodau, 2009) indicating an important electron flow between solid phases during these cycles. Thus, the regeneration of dissolved electron acceptors, up to $\sim 35 \mathrm{mmol}$ electron equivalents $\mathrm{m}^{-2} \mathrm{~d}^{-1}$ (Fig. 10), was most likely small in comparison to that occurring in the solid phase. Adding these 157 mmol electron acceptor equivalents $\mathrm{m}^{-2} \mathrm{~d}^{-1} \quad$ (Knorr and Blodau, 2009) to our balance would account for up to $54 \%$ of the unexplained $\mathrm{O}_{2}$ consumed shown in Fig. 11a. This implies that our gas turnover estimates, which are inaccurate, but conservative and should contain the same bias for $\mathrm{O}_{2}$ than for $\mathrm{CO}_{2}$, would not be fully explained by the renewal of electron acceptors. In this regard, a remaining pool of 3000 to $20000 \mathrm{mmol}$ electron equivalents $\mathrm{m}^{-2}$ (depending on the drying, $\mathrm{D}$ or $\mathrm{C}$ plots) would be still required to close the balance.

Electron accepting processes by humic substances have been experimentally demonstrated in laboratory conditions for both dissolved and solid phases and have been shown to lower methane release in acidic bog peat (Aeschbacher et al., 2010; Blodau and Deppe, 2012; Roden et al., 2010). Although not quantified under in situ conditions, this could have been a mechanism to explain the remaining $\mathrm{O}_{2}$ consumption. In this regard, based on further estimates using the bulk density of the profiles and a peat carbon content of $40 \%$ (Knorr et al., 2008a; Reiche et al., 2008), the necessary electron accepting capacity of peat OM to close the budget during drying could have ranged between 0.28 and 2.26 mmol electron equivalents $\mathrm{g}^{-1} \mathrm{C}$. Such values fall into the range of previously reported electron accepting capacities in dissolved OM (Blodau et al., 2009; Heitmann et al., 2007), but it remains unknown if such capacities are present and can be utilised over periods of weeks to months. It must be kept in mind that sufficient iron and sulfur species were theoretically present at the site to explain $\mathrm{O}_{2}$ consumption but the quantification of their content in the solid phase and the kinetics of these processes were not evaluated.

\subsection{Redox transition after rewetting}

In line with the greater availability of electron acceptors, $\mathrm{Fe}^{2+}$ release upon rewetting was stronger after more severe drying and also depended on the solid phase ferric iron content. The rates presented in Fig. 10 for the pool of dissolved electron acceptors provide only minimum estimates of the total electron acceptor flow since $\mathrm{Fe}^{2+}$ readily precipitates and the dissolved fraction was shown (Lovley, 1987) to represent merely a $2 \%$ of the $\mathrm{Fe}$ (II) obtained by acid extraction. Precipitation of ferrous sulfides was feasible especially during the rapid redox transition associated to rewetting, which agrees with findings from another minerotrophic fen (Todorova et al., 2005). Sulfate might be rapidly flushed out from peat soils upon rewetting events, but it is not likely to have been important in our peat deposit since sulfate release was relatively well balanced by SR (Fig. 10). Our peat deposit is fed by confined streams and the WT raise was not persistent and neither lead, under natural conditions, to surface flow. These conditions were shown to influence the relevance of sulfate export (Warren et al., 2001). The considerable $\mathrm{SO}_{4}^{2-}$ pools generated during dryings with concentrations of up to $1000 \mu \mathrm{mol} \mathrm{L}^{-1}$ were depleted in 20-30 days upon rewetting (see D2, C1, Fig. 7). Our highest estimate of SR reached in D2 $20.5 \mathrm{mmol} \mathrm{m}^{-2} \mathrm{~d}^{-1}$ if integrated for the $30 \mathrm{~cm}$ or $100 \mathrm{nmol} \mathrm{cm}^{-3} \mathrm{~d}^{-1}$ for a given peat layer. For this site, the highest SR rates determined by a ${ }^{35} \mathrm{~S}$ radiotracer method were also reported for D2 with values reaching $600 \mathrm{nmol} \mathrm{cm}^{-3} \mathrm{~d}^{-1}$ (Knorr et al., 2009). Unlike our data that broadly shows that SR was enhanced after rewetting, this process proceeded fastest upon WT decline in unsaturated peat when quantified with a ${ }^{35} \mathrm{~S}$ radiotracer method (Knorr et al., 2009). The authors attributed this finding to the existence of anaerobic niches fed by $\mathrm{SO}_{4}^{2-}$ produced in a predominantly aerated matrix, allowing for rapid recycling of the sulfur pool in unsaturated peat.

\subsection{Post-rewetting: delay of $\mathrm{CH}_{4}$ production in relation to dry intensity}

We expected the delay in $\mathrm{CH}_{4}$ production to be longer after more severe drying events because of oxygen-induced impairment of methanogens and/or a suppression of methanogenesis due to a raised availability of alternative electron acceptors (Achtnich et al., 1995; Dowrick et al., 2006; Knorr and Blodau, 2009; Ratering and Conrad, 1998; Shannon and White, 1996). At our scale of observation, a strong and inverse zonation of $\mathrm{CH}_{4}$ and $\mathrm{O}_{2}$ concentrations was apparent, as expected from this strictly anaerobic methanogenic guild (Fetzer et al., 1993; Kim et al., 2008). Upon rewetting, methanogenic activity was low, but "immediate" after 
seasonal dryings in $\mathrm{C}$ plots and not completely inhibited despite sulfate levels $\sim 500 \mu \mathrm{mol} \mathrm{L}^{-1}$ (Fig. 8). This finding argues for a presence of reduced microenvironments and effects of root exudation in this peat (Knorr and Blodau, 2009; Knorr et al., 2008a). Considering the whole peat as reference volume, methanogens were resilient and resistant to drought events (Öquist and Sundh, 1998) and active despite sulfate concentrations of about $500 \mu \mathrm{mol} \mathrm{L}{ }^{-1}$. Methanogens have indeed a remarkable tolerance to oxygen as shown in upland soil samples worldwide (Angel et al., 2012). Sulfate reduction broadly suppressed relevant methanogenesis until $\mathrm{SO}_{4}^{2-}$ concentrations declined to levels $\sim 100 \mu \mathrm{mol} \mathrm{L}^{-1}$. The effects of seasonal dryness (C plots 2008) lasted for 40-50 d after rewetting until a recuperation of soil $\mathrm{CH}_{4}$ concentrations occurred to - arbitrarily chosen - values of $\sim 80 \mu \mathrm{mol} \mathrm{L}^{-1}$. In contrast, no or negligible methane accumulation was detected for a year after the reinforced drying in $\mathrm{D}$ plots.

As mentioned, a major limitation for the comparison between treatments is the greater aeration of the upper peat layers in D plots (Fig. 2). The upper layers in this site contributed to most or all $\mathrm{CH}_{4}$ production. The upper $5 \mathrm{~cm}$ contributed $>80 \%$ of the total $\mathrm{CH}_{4}$ produced in $50 \mathrm{~cm}$ profiles in incubations of this fen peat (Estop-Aragonés and Blodau, 2012), which is in agreement with other findings from this site (Reiche et al., 2010). This pattern is also confirmed by the observed $\mathrm{CH}_{4}$ accumulation in upper layers, as discussed below. Thus, the delayed $\mathrm{CH}_{4}$ production after intensified drying in D plots was potentially also influenced by systematic and slight differences in WT between $\mathrm{C}$ and D plots. Comparing seasonal dryings between years (C plots 2008 and 2009), deeper WT decline in 2008 caused a stronger degassing and, thus, depletion of the $\mathrm{CH}_{4}$ pool in peat. However, $\mathrm{CH}_{4}$ accumulation after rewetting was similar both years, despite the colder conditions in 2009. The recovery of $\mathrm{CH}_{4}$ production after rewetting was faster under warmer conditions in this (Estop-Aragonés and Blodau, 2012) and other studies with fen peat (Jerman et al., 2009). Furthermore, methane production increased with temperature and was more temperature sensitive than $\mathrm{CH}_{4}$ consumption (Dunfield et al., 1993). This argues for more severe drought delaying $\mathrm{CH}_{4}$ production upon rewetting in agreement to previous observations (Kettunen et al., 1999).

The observed relation between sulfate regeneration during drying and delay in $\mathrm{CH}_{4}$ accumulation upon rewetting illustrates the intertwined role and importance of peat physicochemical properties when evaluating the impact of dry-wet cycles on belowground redox processes. This relation was controlled by at least TRIS and OM content, in addition to the WT position and fluctuations after rewetting (Fig. S4). For a given dry-wet cycle, profiles where drying led to highest sulfate release ( $\mathrm{C} 1$ and D2) were also those with faster SR and sooner/stronger $\mathrm{CH}_{4}$ accumulation after rewetting, presumably because of higher OM content (Figs. 4 and 7, Table 1). Higher OM content potentially enhanced respiration
(Segers, 1998) and increasing OM usually led to higher $\mathrm{CH}_{4}$ production also in peat grasslands (Best and Jacobs, 1997). A weakened SR, and stronger suppression of $\mathrm{CH}_{4}$ production, occurred in profiles with low OM content. Comparing the responses in $\mathrm{C} 2$ and $\mathrm{C} 3$, which have similar TRIS content and WT, but differ in OM, we can conclude that drought events caused a stronger impact on the post-drought soil $\mathrm{CH}_{4}$ accumulation when the OM content was lower. Interestingly, however, lower OM content implied higher peat compaction, thus, favouring higher moisture content and anoxia and, consequently, a comparatively faster $\mathrm{CH}_{4}$ accumulation occurred in the upper layers. If this faster accumulation results from a lower diffusivity in more compacted peat or from a higher production, we unfortunately cannot say. Noteworthy, $\mathrm{CH}_{4}$ production occurred in the unsaturated zone, above the WT, and was maintained in those peats with higher compaction $(\approx$ higher moisture retention) despite WT declined to $-20 \mathrm{~cm}$. Although maximum $\mathrm{CH}_{4}$ production is usually reported to occur below the water table, previous findings already showed $\mathrm{CH}_{4}$ production to be sustained in unsaturated peat during dryings (Kettunen et al., 1999; Knorr et al., 2008b). The most important difference to previous reports is that production in the unsaturated zone took place in the uppermost layer in our site, whereas it did in deeper peat horizons observed elsewhere (Kettunen et al., 1999). This is important because the methane flux released may be enhanced when the transport distance to the atmosphere is short.

Important for the climate change feedback, $\mathrm{CH}_{4}$ emission results from $\mathrm{CH}_{4}$ production, accumulation, diffusive transport and oxidation by methanotrophs (Jaatinen et al., 2005; Popp et al., 2000), and it is influenced by vascular plant mediated production and transport (Strack et al., 2006). Postdrought methane emissions in peat cores of a gully mire undergoing drying in a perfusion system (WT at $20 \mathrm{~cm}$ for 4 weeks) were persistently lower during at least the monitored rewetting period of 5 weeks (Dowrick et al., 2006). Chamber measurements of $\mathrm{CH}_{4}$ fluxes performed in our site in 2008 showed that emissions were generally lower in D plots in comparison to $\mathrm{C}$ plots, but did not follow a simple increasing trend over time after rewetting (J. Köpp, personal communication, 2012), as we observed it for soil $\mathrm{CH}_{4}$ accumulation. Methane fluxes were potentially influenced by the depth of $\mathrm{CH}_{4}$ production and the peat aeration thickness. In this regard, lowest and highest $\mathrm{CH}_{4}$ emissions were generally observed in D3 and C3 plot, respectively (J. Köpp, personal communication, 2012), which strongly differed in terms of oxygen penetration. Considering that gas exchange is strongly regulated by vegetation, the impact of WT change on potential succession is likely crucial (Strack et al., 2006). In this regard, it is worth mentioning that flooding strongly boosted this potential succession towards Sphagnum whose cover remarkably increased. 


\subsection{Flooding}

Despite the continuous supply of electron acceptors with the irrigate, $\mathrm{CH}_{4}$ production, which dominates in the top layer, was maintained and led to $\mathrm{CH}_{4}$ accumulation suggesting that methanogenic microniches existed, as previously inferred (Knorr et al., 2008a). The observed response would have started earlier and been stronger under natural flooding although it cannot be ruled out that the effects from the drought of the previous years had lingered on. The most striking process during flooding was probably the accumulation of acetate and hydrogen, which otherwise did not occur under natural conditions and has been reported for bogs (Shannon and White, 1996). Consumption of these substrates was, thus, potentially faster than their production throughout the year indicating that fermentation limited respiratory and methanogenic activity (Appelo and Postma, 2005). Flooding led to a decoupling of terminal respiration and fermentation. Such decoupling has been documented for bog peat in incubations (Hines et al., 2001) and under field conditions (Duddleston et al., 2002; Shannon and White, 1996). Fermentation might, thus, become also in fens, at least when flooded, the main terminal OM degradation process. Such response may also be expected in systems with intermittent flooding such as by reservoir creation or beaver pond formation.

Methanogenesis, SR and FeR are generally expected to exclude each other since microorganisms mediating these processes compete for acetate and $\mathrm{H}_{2}$. We observed an apparent co-existence of these processes during flooding (Fig. S3), which again argues for the existence of microenvironments (Knorr and Blodau, 2009). Co-occurrence of TEAPs was also shown in anaerobic incubations for upland soils (Peters and Conrad, 1996) and takes place when the rate of a TEAP becomes too small to lower $\mathrm{H}_{2}$ and acetate concentrations to thermodynamic threshold levels. Assuming a given $\mathrm{H}_{2}$ (or acetate) production via fermentation, upon depletion of electron acceptors, FeR and SR rates decrease and, thus, cannot maintain the low range of $\mathrm{H}_{2}$ (or acetate) concentrations, which excludes methanogens because of their greater substrate threshold (Conrad, 1999). In addition to acetate and $\mathrm{H}_{2}$, some methanogens can also use other reduced intermediates such as other organic acids and alcohols (Ferry, 1993), which are more likely to be formed when the $\mathrm{H}_{2}$ pool increases due to excess of fermentable substrates supply (Schink, 1997). However, little stimulation of methanogenesis in incubations from this fen occurred upon methanol additions (Wust et al., 2009), which suggests that methanol was not important as an alternative. Sulfate levels were up to $\sim 100 \mu \mathrm{mol} \mathrm{L}^{-1}$ during flooding, a concentration apparently low enough to allow for relevant methanogenic activity, at those rates of provision of $\mathrm{H}_{2}$ and acetate. These concentrations are in the range of experiments in bog peat monoliths, where addition of sulfate at concentrations above $250 \mu \mathrm{mol} \mathrm{L}-1$ reduced methanogenesis, but levels of 50 and $100 \mu \mathrm{mol} \mathrm{L}^{-1}$ did not substantially
(Watson and Nedwell, 1998). Methanogenesis and SR cooccurrence has been reported at higher sulfate concentrations $\left(\sim 200-300 \mu \mathrm{mol} \mathrm{L}^{-1}\right)$ in cores from bogs with decomposed peats (Wieder et al., 1990). Findings from incubations for this fen peat also indicated a co-occurrence of FeR and methanogenesis despite $\mathrm{Fe}(\mathrm{OH})_{3}$ additions (Reiche et al., 2008).

The processes evaluated could not explain the DIC production during flooding (Fig. 11b) and further considerations are needed to find an explanation. A potential contribution to $\mathrm{CO}_{2}$ production would be reduction of solid phase ferric iron. We estimated that a reduction of only 4 to $7 \%$ of the reactive ferric iron pool in the solid phase would have been adequate to form the unexplained $\mathrm{CO}_{2}$. However, concentrations of dissolved $\mathrm{Fe}^{2+}$ should then have risen to a level 24 times higher than detected. In our consideration an additional sink for ferrous iron would be required. If $\mathrm{FeS}_{2}$ or $\mathrm{FeS}$ precipitated, the required $\mathrm{SO}_{4}^{2-}$ would have been about $4500 \mathrm{mmol} \mathrm{SO}_{4}^{2-} \mathrm{m}^{-2}$ during the flooded period. In this regard, the $\mathrm{SO}_{4}^{2-}$ provision with the irrigate that was permanently discharged was about 10 times higher and, thus, such sulfate demand may have been fulfilled in case those processes took place. The reduction of this potential sulfate pool would also strongly decrease the ferric iron pool necessary to close the budget. This formation of ferrous sulfides was observed in prolonged wet treatments in this peat (Knorr and Blodau, 2009), but no analysis of the TRIS content was performed after flooding to confirm and quantify such a mechanism in this study. The cycling of sulfur has been proposed to play an important role on anaerobic respiration in this fen (Pester et al., 2012), but the origin of the oxidation power necessary for the reoxidation of reduced sulfur has not been determined nor quantified. The provision of oxygen in soil via roots of Carex spp. has been demonstrated (Mainiero and Kazda, 2005) and could account for additional recycling of electron acceptors in our site. Also, additional $\mathrm{CO}_{2}$ formed via fermentation has been claimed as an important source during anaerobic $\mathrm{CO}_{2}$ production not accounted for in such balances (Duddleston et al., 2002; Vile et al., 2003). Net acetogenesis was negligible in our budget, but the accumulation of $\mathrm{H}_{2}$ and acetate (and DOC, not shown) suggests that additional fermentation intermediates (Schink, 1997), which we did not measure, but accumulated in incubations using this fen peat (Hamberger et al., 2008; Wust et al., 2009), could have been also formed potentially contributing thus to the balance.

\section{Conclusions}

Climate change induced shifts in hydrological conditions alter organic matter decomposition rates and pathways. Both the intermittent oxygenation of peat soils during seasonal drying and moderate water table fluctuations favour higher $\mathrm{CO}_{2}$ and lower $\mathrm{CH}_{4}$ production when compared to flooding, 
which favoured fermentation as terminal process. Peat physical properties influenced the key relation WT change-AFP change and compacted peat prevented oxygen penetration despite moderate WT decline, delayed the regeneration of electron acceptors and favoured methane production under unsaturated conditions suggesting the existence of microniches under transient redox conditions. More intense drought broadly led to greater electron acceptor regeneration and the depth of WT decline, rather than the drying duration, was most important to this regeneration process. Oxidation was fast compared to the temporal scale of drought, which suggests that more frequent drought has a bigger effect than more intense drought in minerotrophic sites. Drying, thus, diverted the electron flow from methanogenesis towards iron and sulfate reduction after rewetting and this way lowered soil $\mathrm{CH}_{4}$ accumulation for weeks to months. Despite methanogenesis was broadly suppressed by sulfate reduction, the delay in methane release was not necessarily related to the greater availability of electron acceptors after more intense drying, but to OM content and reactivity, which favoured a stronger recovery of $\mathrm{CH}_{4}$ accumulation. The depth distribution of methane production determines the relevance of this suppression since the uppermost peat layer concentrates the highest respiratory (and methanogenic) activity and, thus, rapidly depletes the pool of electron acceptors generated during drying compared to less productive horizons.

\section{Supplementary material related to this article is

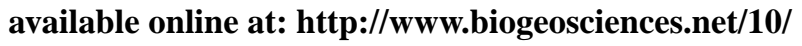 421/2013/bg-10-421-2013-supplement.pdf.}

Acknowledgements. The study was funded by the German Research Foundation (DFG) grant BL 563/7-3 to C. Blodau as part of the Research Unit 562 (soil processes under extreme meteorological boundary conditions). We thank U. Hell, A. Kolb and G. Müller for technical assistance in the field, S. Irl, S. Würzer, J. Pfister, M. Friedel, D. Heidel, T. Broder and B. Wagner for assistance with sampling, and J. Eckert, M. Rohr, S. Hammer, K. Söllner and H. Zier for lab assistance.

Edited by: T. Laurila

\section{References}

Achtnich, C., Bak, F., and Conrad, R.: Competition for electrondonors among nitrate reducers, ferric iron reducers, sulfate reducers, and methanogens in anoxic paddy soil, Biol. Fert. Soils, 19, 65-72, 1995.

Aeschbacher, M., Sander, M., and Schwarzenbach, R. P.: Novel Electrochemical Approach to Assess the Redox Properties of Humic Substances, Environ. Sci. Technol., 44, 87-93, 2010.
Ahmad, A. R. and Nye, P. H.: Coupled Diffusion and Oxidation of Ferrous Iron in Soils., 1. Kinetics of Oxygenation of Ferrous Iron in Soil Suspension, J. Soil Sci., 41, 395-409, 1990.

Angel, R., Claus, P., and Conrad, R.: Methanogenic archaea are globally ubiquitous in aerated soils and become active under wet anoxic conditions, ISME J., 6, 847-862, 2012.

Appelo, C. A. J. and Postma, D.: Geochemistry: groundwater and pollution, 2nd Edn., A. A. Balkema Publishers, Leiden, The Netherlands, 2005.

Aurela, M., Riutta, T., Laurila, T., Tuovinen, J. P., Vesala, T., Tuittila, E. S., Rinne, J., Haapanala, S., and Laine, J.: $\mathrm{CO}_{2}$ exchange of a sedge fen in southern Finland - The impact of a drought period, Tellus B, 59, 826-837, 2007.

Best, E. P. H. and Jacobs, F. H. H.: The influence of raised water table levels on carbon dioxide and methane production in ditchdissected peat grasslands in the Netherlands, Ecol. Eng., 8, 129144, 1997.

Blodau, C., Bauer, M., Regenspurg, S., and Macalady, D.: Electron accepting capacity of dissolved organic matter as determined by reaction with metallic zinc, Chem. Geol., 260, 186-195, 2009.

Blodau, C. and Deppe, M.: Humic acid addition lowers methane release in peats of the mer Bleue bog, Canada, Soil Biol. Biochem., 52, 96-98 doi:10.1016/j.soilbio.2012.04.023, 2012.

Conrad, R.: Contribution of hydrogen to methane production and control of hydrogen concentrations in methanogenic soils and sediments, Fems Microbiol. Ecol., 28, 193-202, 1999.

Cordruwisch, R., Seitz, H. J., and Conrad, R.: The Capacity of Hydrogenotrophic Anaerobic-Bacteria to Compete for Traces of Hydrogen Depends on the Redox Potential of the Terminal Electron-Acceptor, Arch. Microbiol., 149, 350-357, 1988.

Deppe, M., McKnight, D. M., and Blodau, C.: Effects of ShortTerm Drying and Irrigation on Electron Flow in Mesocosms of a Northern Bog and an Alpine Fen, Environ. Sci. Technol., 44, 80-86, 2010.

Dowrick, D. J., Freeman, C., Lock, M. A., and Reynolds, B.: Sulphate reduction and the suppression of peatland methane emissions following summer drought, Geoderma, 132, 384-390, 2006.

Duddleston, K. N., Kinney, M. A., Kiene, R. P., and Hines, M. E.: Anaerobic microbial biogeochemistry in a northern bog: Acetate as a dominant metabolic end product, Global Biogeochem. Cy., 16, 11-1-11-9, doi:10.1029/2001GB001402, 2002.

Dunfield, P., Knowles, R., Dumont, R., and Moore, T. R.: Methane Production and Consumption in Temperate and Sub-Arctic Peat Soils - Response to Temperature and Ph, Soil Biol. Biochem., 25, 321-326, 1993.

Elberling, B., Askaer, L., Jørgensen, C. J., Joensen, H. P., Kühl, M., Glud, R. N., and Lauritsen, F. R.: Linking soil $\mathrm{O}_{2}, \mathrm{CO}_{2}$, and $\mathrm{CH}_{4}$ concentrations in a wetland soil: implications for $\mathrm{CO}_{2}$ and $\mathrm{CH}_{4}$ fluxes, Environ. Sci. Technol., 45, 3393-3399, doi:10.1021/es103540k, 2011.

Estop-Aragonés, C. and Blodau, C.: Effects of experimental drying intensity and duration on respiration and methane production recovery in fen peat incubations, Soil Biol. Biochem., 47, 1-9, 2012.

Estop-Aragonés, C., Knorr, K.-H., and Blodau, C.: Controls on in situ oxygen and dissolved inorganic carbon dynamics in peats of a temperate fen, J. Geophys. Res., 117, G02002, doi:10.1029/2011JG001888, 2012. 
Ferry, J. G.: Methanogenesis: ecology, physiology, biochemistry and genetics, Chapman \& Hall, 1993.

Fetzer, S., Bak, F., and Conrad, R.: Sensitivity of methanogenic bacteria from paddy soil to oxygen and desiccation, Fems Microbiol. Ecol., 12, 107-115, 1993.

Firbas, F. and v. Rochow, M.: Zur Geschichte der Moore und Wälder im Fichtelgebirge, Forstwissenschaftliches Centralblatt, 75, 367-380, 1956.

Freeman, C., Hudson, J., Lock, M. A., Reynolds, B., and Swanson, C. A.: Possible Role of Sulfate in the Suppression of Wetland Methane Fluxes Following Drought, Soil Biol. Biochem., 26, 1439-1442, 1994.

Hamberger, A., Horn, M. A., Dumont, M. G., Murrell, J. C., and Drake, H. L.: Anaerobic consumers of monosaccharides in a moderately acidic fen, Appl. Environ. Microb., 74, 3112-3120, 2008.

Heitmann, T., Goldhammer, T., Beer, J., and Blodau, C.: Electron transfer of dissolved organic matter and its potential significance for anaerobic respiration in a northern bog, Global Change Biol., 13, 1771-1785, 2007.

Hines, M. E., Duddleston, K. N., and Kiene, R. P.: Carbon flow to acetate and C-1 compounds in northern wetlands, Geophys. Res. Lett., 28, 4251-4254, 2001.

Hoehler, T. M., Alperin, M. J., Albert, D. B., and Martens, C. S.: Thermodynamic control on hydrogen concentrations in anoxic sediments. Geochimi. Cosmochim. Ac., 62, 1745-1756, 1998.

Hofmann, K. and Hamm, R.: Determination of Hydrogen Sulfide with N,N-Dimethyl-P-Phenylene Diamine and Iron(III) Chloride, Zeitschrift Für Analytische Chemie, Fresenius, 232, 167, 1967.

Hogg, E. H., Lieffers, V. J., and Wein, R. W.: Potential carbon losses from peat profiles - Effects of temperature, drought cycles, and fire, Ecol. Appl., 2, 298-306, 1992.

Jaatinen, K., Tuittila, E. S., Laine, J., Yrjala, K., and Fritze, H.: Methane-oxidizing bacteria in a Finnish raised mire complex: Effects of site fertility and drainage, Microb. Ecol., 50, 429-439, 2005.

Jerman, V., Metje, M., Mandic̀-Mulec, I., and Frenzel, P.: Wetland restoration and methanogenesis: the activity of microbial populations and competition for substrates at different temperatures, Biogeosciences, 6, 1127-1138, doi:10.5194/bg-6-11272009, 2009.

Kettunen, A., Kaitala, V., Lehtinen, A., Lohila, A., Alm, J., Silvola, J., and Martikainen, P. J.: Methane production and oxidation potentials in relation to water table fluctuations in two boreal mires, Soil Biol. Biochem., 31, 1741-1749, 1999.

Kim, S. Y., Lee, S. H., Freeman, C., Fenner, N., and Kang, H.: Comparative analysis of soil microbial communities and their responses to the short-term drought in bog, fen, and riparian wetlands, Soil Biol. Biochem., 40, 2874-2880, 2008

Knorr, K. H. and Blodau, C.: Impact of experimental drought and rewetting on redox transformations and methanogenesis in mesocosms of a northern fen soil, Soil Biol. Biochem., 41, 1187-1198, 2009.

Knorr, K.-H., Glaser, B., and Blodau, C.: Fluxes and ${ }^{13} \mathrm{C}$ isotopic composition of dissolved carbon and pathways of methanogenesis in a fen soil exposed to experimental drought, Biogeosciences, 5, 1457-1473, doi:10.5194/bg-5-1457-2008, 2008a.
Knorr, K. H., Oosterwoud, M. R., and Blodau, C.: Experimental drought alters rates of soil respiration and methanogenesis but not carbon exchange in soil of a temperate fen, Soil Biol. Biochem., 40, 1781-1791, 2008b.

Knorr, K. H., Lischeid, G., and Blodau, C.: Dynamics of redox processes in a minerotrophic fen exposed to a water table manipulation, Geoderma, 153, 379-392, 2009.

Koehler, B., Zehe, E., Corre, M. D., and Veldkamp, E.: An inverse analysis reveals limitations of the soil- $\mathrm{CO}_{2}$ profile method to calculate $\mathrm{CO}_{2}$ production and efflux for well-structured soils, Biogeosciences, 7, 2311-2325, doi:10.5194/bg-7-2311-2010, 2010.

Lerman, A.: Geochemical Processes - Water and sediment environments. Krieger Publisching Company, Inc., Florida, 1988.

Lovley, D. R.: Organic-Matter Mineralization with the Reduction of Ferric Iron - a Review, Geomicrobiol. J., 5, 375-399, 1987.

Mainiero, R. and Kazda, M.: Effects of Carex rostrata on soil oxygen in relation to soil moisture, Plant Soil, 270, 311-320, 2005.

Meehl, G. A., Stocker, T. F., Collins, W. D., Friedlingstein, P., Gaye, A. T., Gregory, J. M., Kitoh, A., Knutti, R., Murphy, J. M., Noda, A., Raper, S. C. B., Watterson, I. G., Weaver, A. J., and Zhao, Z.-C.: Global Climate Projections, in: Climate Change 2007: The Physical Science Basis, Contribution of Working Group I to the Fourth Assessment Report of the Intergovernmental Panel on Climate Change, edited by: Solomon, S., Qin, D., Manning, M., Chen, Z., Marquis, M., Averyt, K. B., Tignor, M., and Miller, H. L., Cambridge University Press, Cambridge, United Kingdom and New York, NY, USA, 2007.

Minkkinen, K., Laine, J., Shurpali, N. J., Makiranta, P., Alm, J., and Penttila, T.: Heterotrophic soil respiration in forestry-drained peatlands, Boreal Environ. Res., 12, 115-126, 2007.

Mitchell, C. P. J. and Branfireun, B. A.: Hydrogeomorphic controls on reduction-oxidation conditions across boreal upland-peatland interfaces, Ecosystems, 8, 731-747, 2005.

Moldrup, P., Poulsen, T. G., and Yamaguchi, T.: Modeling diffusion and reaction in soils 1 , A diffusion and reaction corrected finite difference calculation scheme - Response, Soil Sci., 162, 844849, 1997.

Öquist, M. and Sundh, I.: Effects of a transient oxic period on mineralization of organic matter to $\mathrm{CH}_{4}$ and $\mathrm{CO}_{2}$ in anoxic peat incubations, Geomicrobiol. J., 15, 325-333, 1998.

Parish, F., Sirin, A., Charman, D., Joosten, H., Minayeva, T., Silvius, M., and Stringer, L.: Assessment on Peatlands, Biodiversity and Climate Change: Main report, Chapter 6, Global Environment Centre, Kuala Lumpur and Wetlands International, Wageningen, 2008.

Pester, M., Knorr, K. H., Friedrich, M. W., Wagner, M., and Loy, A.: Sulfate-reducing microorganisms in wetlands - fameless actors in carbon cycling and cliamte change, Frontiers in Microbiology, 3, 1-19, doi:10.3389/fmicb.2012.00072, 2012.

Peters, V. and Conrad, R.: Sequential reduction processes and initiation of $\mathrm{CH} 4$ production upon flooding of oxic upland soils, Soil Biol. Biochem., 28, 371-382, 1996.

Pingintha, N., Leclerc, M. Y., Beasley, J. P., Zhang, G. S., and Senthong, $\mathrm{C}$.: Assessment of the soil $\mathrm{CO}_{2}$ gradient method for soil $\mathrm{CO}_{2}$ efflux measurements: comparison of six models in the calculation of the relative gas diffusion coefficient, Tellus B, 62, 47-58, 2010.

Popp, T. J., Chanton, J. P., Whiting, G. J., and Grant, N.: Evaluation of methane oxidation in the rhizosphere of a Carex dominated fen 
in north central Alberta, Canada, Biogeochemistry, 51, 259-281, 2000.

Ratering, S. and Conrad, R.: Effects of short-term drainage and aeration on the production of methane in submerged rice soil, Global Change Biol., 4, 397-407, 1998.

Reiche, M., Torburg, G., and Kusel, K.: Competition of Fe(III) reduction and methanogenesis in an acidic fen, Fems Microbiol. Ecol., 65, 88-101, 2008.

Reiche, M., Gleixner, G., and Küsel, K.: Effect of peat quality on microbial greenhouse gas formation in an acidic fen, Biogeosciences, 7, 187-198, doi:10.5194/bg-7-187-2010, 2010.

Roden, E. E., Kappler, A., Bauer, I., Jiang, J., Paul, A., Stoesser, R., Konishi, H., and Xu, H. F.: Extracellular electron transfer through microbial reduction of solid-phase humic substances, Nat. Geosci., 3, 417-421, 2010.

Sander, R.: Compilation of Henry's Law Constants for Inorganic and Organic Species of Potential Importance in Environmental Chemistry (Version 3), http://www.henrys-law.org, 1999.

Schink, B.: Energetics of syntrophic cooperation in methanogenic degradation, Microbiol. Mol. Biol. R., 61, 262-280, 1997.

Segers, R.: Methane production and methane consumption: a review of processes underlying wetland methane fluxes, Biogeochemistry, 41, 23-51, 1998.

Shannon, R. D. and White, J. R.: The effects of spatial and temporal variations in acetate and sulfate on methane cycling in two Michigan peatlands. Limnol. Oceanogr., 41, 435-443, 1996.

Silvola, J., Alm, J., Ahlholm, U., Nykanen, H., and Martikainen, P. $\mathrm{J} .: \mathrm{CO}_{2}$ fluxes from peat in boreal mires under varying temperature and moisture conditions, J. Ecol., 84, 219-228, 1996.

Strack, M., Waller, M. F., and Waddington, J. M.: Sedge succession and peatland methane dynamics: A potential feedback to climate change, Ecosystems, 9, 278-287, 2006.
Stumm, W. and Morgan, J. J.: Aquatic chemistry - Chemical equilibria and rates in natural waters, 3rd Edn., Wiley Interscience, 1996.

Tamura, H., Goto, K., Yotsuyan, T., and Nagayama, M.: Spectrophotometric Determination of Iron(Ii) with 1,10Phenanthroline in Presence of Large Amounts of Iron(Iii), Talanta, 21, 314-318, 1974.

Todorova, S. G., Siegel, D. I., and Costello, A. M.: Microbial Fe(III) reduction in a minerotrophic wetland - geochemical controls and involvement in organic matter decomposition, Appl. Geochem., 20, 1120-1130, 2005.

Vile, M. A., Bridgham, S. D., and Wieder, R. K.: Response of anaerobic carbon mineralization rates to sulfate amendments in a boreal peatland, Ecol. Appl., 13, 720-734, 2003.

Warren, F. J., Waddington, J. M., Bourbonniere, R. A., and Day, S. M.: Effect of drought on hydrology and sulphate dynamics in a temperate swamp, Hydrol. Process., 15, 3133-3150, 2001.

Watson, A. and Nedwell, D. B.: Methane production and emission from peat: The influence of anions (sulphate, nitrate) from acid rain, Atmos. Environ., 32, 3239-3245, 1998.

Wieder, R. K., Yavitt, J. B., and Lang, G. E.: Methane Production and Sulfate Reduction in 2 Appalachian Peatlands, Biogeochemistry, 10, 81-104, 1990.

Wust, P. K., Horn, M. A., and Drake, H. L.: Trophic links between fermenters and methanogens in a moderately acidic fen soil, Environ. Microbiol., 11, 1395-1409, 2009.

Yavitt, J. B., Williams, C. J., and Wieder, R. K.: Production of methane and carbon dioxide in peatland ecosystems across North America: Effects of temperature, aeration, and organic chemistry of peat, Geomicrobiol. J., 14, 299-316, 1997. 